\title{
The Presynaptic Component of the Serotonergic System is Required for Clozapine's Efficacy
}

\author{
Prem N Yadav', Atheir I Abbas ${ }^{2}$, Martilias S Farrell', Vincent Setola ${ }^{1,3}$, Noah Sciaky', Xi-Ping Huang ${ }^{1,3}$, \\ Wesley K Kroeze', LaTasha K Crawford ${ }^{4}$, David A Piel ${ }^{4}$, Michael J Keiser ${ }^{5}$, John J Irwin ${ }^{5}$, Brian K Shoichet ${ }^{5}$, \\ Evan S Deneris ${ }^{6}$, Jay Gingrich ${ }^{7}$, Sheryl G Beck*,4 and Bryan L Roth ${ }^{*, 3,8}$ \\ 'Department of Pharmacology, University of North Carolina, Chapel Hill, NC, USA; ${ }^{2}$ Department of Biochemistry, Case Western Reserve \\ University Medical School, Cleveland, OH, USA; ${ }^{3}$ National Institute of Mental Heath Psychoactive Drug Screening Program, University of North \\ Carolina, Chapel Hill, NC, USA; ${ }^{4}$ Department of Anesthesiology, Children's Hospital of Philadelphia Research Institute, Philadelphia, PA, USA; \\ ${ }^{5}$ Department of Pharmaceutical Chemistry, University of California, San Francisco, CA, USA; ${ }^{6}$ Department of Neurosciences, Case Western \\ Reserve University Medical School, Cleveland, OH, USA; 'Department of Psychiatry, Columbia University College of Physicians and Surgeons, \\ New York, NY, USA and ${ }^{8}$ Departments of Pharmacology, Medicinal Chemistry and Psychiatry, Lineberger Cancer Center, University of North \\ Carolina, Chapel Hill, NC, USA
}

\begin{abstract}
Clozapine, by virtue of its absence of extrapyramidal side effects and greater efficacy, revolutionized the treatment of schizophrenia, although the mechanisms underlying this exceptional activity remain controversial. Combining an unbiased cheminformatics and physical screening approach, we evaluated clozapine's activity at $>2350$ distinct molecular targets. Clozapine, and the closely related atypical antipsychotic drug olanzapine, interacted potently with a unique spectrum of molecular targets. This distinct pattern, which was not shared with the typical antipsychotic drug haloperidol, suggested that the serotonergic neuronal system was a key determinant of clozapine's actions. To test this hypothesis, we used pet $I^{-1-}$ mice, which are deficient in serotonergic presynaptic markers. We discovered that the antipsychotic-like properties of the atypical antipsychotic drugs clozapine and olanzapine were abolished in a pharmacological model that mimics NMDA-receptor hypofunction in pet $1^{-1-}$ mice, whereas haloperidol's efficacy was unaffected. These results show that clozapine's ability to normalize NMDA-receptor hypofunction, which is characteristic of schizophrenia, depends on an intact presynaptic serotonergic neuronal system.

Neuropsychopharmacology (20II) 36, 638-65I; do:I0.1038/npp.2010.195; published online 3 November 2010
\end{abstract}

Keywords: serotonin; schizophrenia; clozapine; petl; antipsychotic drugs

\section{INTRODUCTION}

Schizophrenia, a devastating illness affecting nearly $1 \%$ of the world's population, appears to be a genetically heterogeneous disorder with no single major risk allele (Purcell et al, 2009; Shi et al, 2009; Stefansson et al, 2009; Stefansson et al, 2008). This extreme genetic heterogeneity will make it difficult, if not impossible, to develop new medications that specifically target the presumably dysregulated pathways. Despite the polygenic nature of

*Correspondence: Dr BL Roth, Department of Pharmacology, University of North Carolina, National Institute of Mental Heath Psychoactive Drug Screening Program, Chapel Hill, NC, 27516, USA, Tel: + I 9199667535 , Fax: + I919 843 5788, E-mail: bryan_roth@ med.unc.edu or Dr SG Beck, Department of Anesthesiology, Children's Hospital of Philadelphia Research Institute, Philadelphia, PA 19104, USA, Tel: + I 215590 065I, Fax: + I 215590 4l07, E-mail: becks@email.chop.edu

Received 25 August 2010; revised 27 September 2010; accepted 27 September 2010 the illness, however, the symptoms of schizophrenia can be reduced, to various degrees of efficacy, by antipsychotic medications (Lieberman et al, 2005). Of the various medications currently available to treat schizophrenia, clozapine is uniquely effective (Kane et al, 1988). Indeed, clozapine - a drug discovered $>50$ years ago (Hippius, 1999) - has long been known to effectively treat schizophrenia without associated extrapyramidal symptoms (EPS) (Angst et al, 1971). Clozapine has also been demonstrated to be uniquely effective in reducing suicidality (Meltzer et al, 2003; Meltzer and Okayli, 1995). Clozapine has a number of serious side effects, including a nearly $1 \%$ risk of fatal agranulocytosis (Senn et al, 1977), limiting its use to treatment-resistant or treatmentintolerant patients. The discovery of clozapine's characteristic ability to treat schizophrenia without inducing EPS led to the development of the so-called 'atypical' antipsychotic drugs, which are now among the most widely prescribed neuropsychiatric medications (Lieberman et al, 2005). 
For many years, it has been appreciated that clozapine and related atypical antipsychotics have extraordinarily robust pharmacological profiles, with potent interactions at a large number of mainly postsynaptically localized biogenic amine receptors, including several serotonin (Meltzer et al, 1989; Peroutka et al, 1981; Roth et al, 1992; Roth et al, 1994), dopamine (Creese et al, 1976; Van Tol et al, 1991), adrenergic (Enna et al, 1976), and muscarinic (Bolden et al, 1992; Miller and Hiley, 1974) G-proteincoupled receptors (GPCRs) (Roth et al, 2004). It is currently unknown, and the subject of considerable controversy, which, if any, of these pharmacological properties are essential for either the unique spectrum of efficacy or the unusual sideeffect profile of clozapine. One aspect of their actions that has recently become clear, however, is the observation that only clozapine and the closely related atypical antipsychotic drugs are effective in genetic and pharmacological models that mimic the NMDA-receptor hypofunction of schizophrenia (Abbas et al, 2009; Bakshi et al, 1994; Belforte et al, 2010; Mohn et al, 1999) Without a clearer understanding of the molecular and neuronal substrates responsible for these actions, it will remain difficult, if not impossible, to develop new antipsychotic drugs with either improved efficacies or fewer side effects (Conn and Roth, 2008).

To discover the molecular and neuronal determinants of clozapine's actions, we utilized our unbiased chemical, biological, and cheminformatic approaches to deconstruct clozapine's molecular and cellular actions (Armbruster and Roth, 2005; Keiser et al, 2007; Keiser et al, 2009). We discovered that clozapine and the related atypical antipsychotic drug olanzapine, but not haloperidol, displayed a unique spectrum of activity at selected molecular targets. This pattern of activity suggested to us that the serotonin neuronal phenotype was an essential mediator of clozapine's actions. The ETS-domain transcription factor pet 1 has recently emerged as a key determinant of the serotonergic phenotype (Hendricks et al, 1999; Hendricks et al, 2003; Jensen et al, 2008) of neurons, and pet $1^{-1-}$ mice almost completely lack the presynaptic component of the serotonergic phenotype, including tryptophan hydroxylase 2 (Tph2), the serotonin transporter (SERT), the vesicular monoamine transporter 2 , and aromatic amino acid decorboxylase in dorsal raphe neurons of adult KO mice. These mice express only $20 \%$ of the adult level of 5-HT (Hendricks et al, 2003). We discovered that genetically induced deletion of the presynaptic component of the serotonergic neuronal system selectively abolished the ability of clozapine to normalize NMDA-receptor hypofunction in mouse pharmacological models of schizophrenia. Importantly, genetic deletion of the main postsynaptic receptor implicated in clozapine's actions (HTR2A) did not abolish clozapine's therapeutic actions. These results demonstrate an unexpectedly essential role for the presynaptic component of the serotonin neuronal system for clozapine's therapeutic actions.

\section{MATERIALS AND METHODS}

\section{Mice}

A detailed description of how the pet $1^{-/-}$mice were generated is provided elsewhere (Hendricks et al, 2003).
All experiments were approved by the institutional animal care and use committee at the University of North Carolina, Chapel Hill. Mice were housed under standard conditions $-12 \mathrm{~h} \mathrm{light/dark} \mathrm{cycle} \mathrm{and} \mathrm{food} \mathrm{and} \mathrm{water} \mathrm{ad} \mathrm{libitum.}$

\section{Radioligand Binding Assays}

For saturation binding assays, brain regions were rapidly microdissected, frozen on dry ice, and then stored at $-80^{\circ} \mathrm{C}$. A Tissue TearorTM (BioSpec Products) was used to homogenize tissue (15 s, 15000 r.p.m.) in ice-cold standard binding buffer (SBB-50 mM Tris- $\mathrm{HCl}, \mathrm{pH} 7.4 ; 10 \mathrm{mM}$ $\mathrm{MgCl}_{2} ; 0.1 \mathrm{mM}$ EDTA). Homogenized tissue was centrifuged for $20 \mathrm{~min}$ at $27000 \mathrm{~g}\left(4^{\circ} \mathrm{C}\right)$; crude membrane pellets were collected and washed two more times in a total of $10 \mathrm{ml}$ of SBB. After the last wash, the membrane pellet was either used immediately for binding, or stored at $-80^{\circ} \mathrm{C}$ until use. Saturation binding assays were performed with the homogenized brain tissue and $\left[{ }^{3} \mathrm{H}\right]$-ketanserin $\left(5-\mathrm{HT}_{2 \mathrm{~A}}\right.$; cortex) or $\left[{ }^{3} \mathrm{H}\right]-\mathrm{WAY} 100635\left(5-\mathrm{HT}_{1 \mathrm{~A}}\right.$, cortex, midbrain, and hippocampus), and then incubated in SBB for $1.5 \mathrm{~h}$ as detailed (Abbas et al, 2009). Nonspecific binding was determined by incubating the reactions with $10 \mu \mathrm{M}$ ritanserin $\left(5-\mathrm{HT}_{2 \mathrm{~A}}\right)$ or $10 \mu \mathrm{M}$ buspirone $\left(5-\mathrm{HT}_{1 \mathrm{~A}}\right)$. Reactions were harvested by vacuum filtration through glass filters $(3 \times$ ice-cold $50 \mathrm{mM}$ Tris, pH 7.4; pH 6.9 at room temperature) and measured by liquid scintillation using a Perkin-Elmer Tri-Carb 2800TR scintillation counter. Nonlinear saturation analysis was done using Graphpad Prism 4.01 to obtain $\mathrm{B}_{\max }$ values, and Bradford protein assays were performed in order to normalize $B_{\max }$ determinations to the amount of protein in each assay.

\section{Western Blotting}

DOI (1-(4-iodo-2,5-dimethoxyphenyl)propan-2-amine hydrochloride) or vehicle was injected intraperitoneally (i.p.) with light restraint to minimize stress effects, and mice were killed $15 \mathrm{~min}$ later by cervical dislocation. Microdissection was performed on ice as quickly as possible. For detection of pERK1/2, tissue was homogenized in $300 \mu \mathrm{l}$ of ice-cold SBB plus protease and phosphatase inhibitor cocktails (Roche Diagnostics, Complete, no. 11697498001; PhosSTOP, no. 04906845001) and 5\% glycerol, and centrifuged for $10 \mathrm{~min}$ at $20-25000 \mathrm{~g}$ and $4{ }^{\circ} \mathrm{C}$. Then, $25-30 \mu \mathrm{g}$ of protein from the supernatant was used to measure phospho- and total ERK1/2 using 10\% SDS-PAGE followed by immunoblotting. The following antibodies were used for western blots in a $1: 1000$ dilution: rabbit polyclonal antip-ERK1/2 antibody (9101L, Cell Signaling), and rabbit polyclonal anti-ERK1/2 antibody (9102L, Cell Signaling). For $5-\mathrm{HT}_{2 \mathrm{~A}}$ receptor immunoblotting, frontal cortex crude membrane preparations were resuspended in cold lysis buffer ( $50 \mathrm{mM}$ Tris-Cl, pH 7.4; $150 \mathrm{mM} \mathrm{NaCl}, 10 \%$ glycerol, $1 \%$ NP-40, $0.5 \%$ Na-deoxycholate, $0.5 \%$ CHAPS, plus protease inhibitor cocktail (Roche Diagnostics) and incubated on ice for $1 \mathrm{~h}$. Detergent-soluble proteins were collected after $20 \mathrm{~min}$ of centrifugation at $4{ }^{\circ} \mathrm{C}$ and $12500 \mathrm{~g}$, and $500 \mu \mathrm{g}(1.0 \mathrm{mg} / \mathrm{ml})$ of protein was incubated with 25-30 $\mu \mathrm{l}$ (packed volume) of wheat germ agglutinin (WGA)conjugated agarose beads (Vector Technology) for a minimum of $2 \mathrm{~h}$ at $4{ }^{\circ} \mathrm{C}$ on a rotary mixer. After three 
washes with $500 \mu \mathrm{l}$ of lysis buffer, WGA-bound proteins were eluted with $40 \mu \mathrm{l}$ of $1 \times$ SDS-sample buffer, and whole eluates were resolved by SDS-PAGE. Rabbit polyclonal anti$5-\mathrm{HT}_{2 \mathrm{~A}}$ receptor antibody (Neuromics, Edina, MN) was used in a 1:500 dilution for $12 \mathrm{~h}$ at $4{ }^{\circ} \mathrm{C}$ for measurement of $5-\mathrm{HT}_{2 \mathrm{~A}}$ receptor protein. We have previously verified the specificity of the anti-5- $\mathrm{HT}_{2 \mathrm{~A}}$ receptor antibody using $5-\mathrm{HT}_{2 \mathrm{~A}} \mathrm{WT}$ and $\mathrm{KO}$ mice cortex tissue by immunoblotting (Magalhaes et al, 2010)

\section{Head-Twitch Response}

As previously detailed (Abbas et al, 2009), mice were injected i.p. with $0.5-5.0 \mathrm{mg} / \mathrm{kg}$ of DOI. Head twitches were counted simultaneously by two observers (live, not on recordings), one of whom was blinded to the genotype, and recorded in 5-min bins for a total period of $30 \mathrm{~min}$ immediately after injection.

\section{Whole-Cell Recording in CA1 Pyramidal and Dorsal Raphe Neurons}

Adult pet $1^{-/-}$and pet ${ }^{+/+}$littermate mice were decapitated, and their heads placed into a beaker containing icecold oxygenated artificial cerebrospinal fluid (aCSF: (in $\mathrm{mM}$ ) sucrose 248, $\mathrm{KCl} 3.0, \mathrm{NaH}_{2} \mathrm{PO}_{4} 1.25, \mathrm{MgSO}_{4} 2.0, \mathrm{CaCl}_{2}$ 2.5 , dextrose 10 , and $\mathrm{NaHCO}_{3} 26$ ) for approximately $10 \mathrm{~min}$. Following this, the brain was removed, $200 \mu \mathrm{m}$ vibratome slices of the hippocampus or the midbrain were made and placed in a holding chamber in a water bath $\left(36^{\circ} \mathrm{C}\right)$ for $1 \mathrm{~h}$, and then maintained at room temperature until used. Single slices were placed in a recording chamber (Warner Instruments, Hamden, CT), and continuously perfused with aCSF $(\mathrm{NaCl} 124 \mathrm{mM}$ replaced sucrose $)$ at $2 \mathrm{ml} / \mathrm{min}$ at $32{ }^{\circ} \mathrm{C}$ maintained by an in-line solution heater $(\mathrm{SH}-27 \mathrm{~B}$, Warner Instruments). Neurons were visualized using a Nikon E600 (Optical Apparatus, Ardmore, PA) upright microscope fitted with a $\times 60$ water-immersion objective, differential interference contrast (DIC) optics, and an infrared filter (IR). Recording pipettes were fashioned on a P-97 micropipette puller (Sutter Instruments, Novato, CA) using borosilicate glass capillary tubing $(1.2 \mathrm{~mm} \mathrm{OD}$, $0.69 \mathrm{~mm}$ ID; Warner Instruments). The electrolyte for recording cellular characteristics was (in $\mathrm{mM}$ ): $\mathrm{K}$ gluconate 130, $\mathrm{NaCl} 5, \mathrm{MgCl}_{2}$ 1, Naphosphocreatinine 10, EGTA 0.02, HEPES 10, MgATP 2, $\mathrm{Na}_{2} \mathrm{GTP} 0.5$, and 0.1\% Biocytin, $\mathrm{pH}$ 7.3. A visualized pyramidal cell in the CA1 subfield of the dorsal hippocampus or a raphe neuron from the ventromedial subfield of the dorsal raphe was approached with the electrode, a giga $\Omega$ seal established, and the cell membrane ruptured to obtain a whole-cell recording using a multiclamp 700B amplifier (Axon Instruments, Foster City, CA). Once the whole cell configuration was obtained, cell characteristics were recorded using current clamp techniques. The cellular characteristics were measured as previously described (Beck et al, 2004). Following the collection of cell characteristics, the pyramidal cell was returned to voltage clamp mode at $-60 \mathrm{mV}$. After a stable baseline was established, 5-carboxyamidotryptamine (5-CT), a 5- $\mathrm{HT}_{1 \mathrm{~A}}$ agonist, to a final concentration of $100 \mathrm{~nm}$ was added to the aCSF, and the change in current was measured. Once a steady-state response was established, the drug was removed from the aCSF and only one cell was recorded per slice. The access resistance and the input resistance were continuously monitored throughout the recording period to assure quality of the recordings. Recordings were abandoned if the access resistance was more than four times the resistance of the electrode, or if the input resistance changed by $>15 \%$. For the dorsal raphe neurons, current clamp recordings were obtained of the hyperpolarization induced by activation of the $5-\mathrm{HT}_{1 \mathrm{~A}}$ receptor by addition of $5-\mathrm{CT}(100 \mathrm{nM})$ to the perfusion buffer. Unpaired $t$-tests were used to test for significance using the statistical package Prism.

\section{Immunohistochemistry}

Adult mice were anesthetized and transcardially perfused

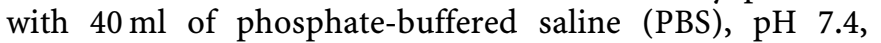
followed by $4 \%$ paraformaldehyde (PFA) in PBS, $\mathrm{pH}$ 7.4. The brains were collected, postfixed overnight at $4{ }^{\circ} \mathrm{C}$ in $4 \%$ PFA, followed by dehydration in a $30 \%$ sucrose $(\mathrm{w} / \mathrm{v})$ solution in PBS overnight at $4{ }^{\circ} \mathrm{C}$. Brain sections $(30 \mu \mathrm{m}$ coronal sections) were permeabilized for $1 \mathrm{~h}$ with $0.4 \%$ Triton X-100 in PBS, and were blocked for $2 \mathrm{~h}$ at room temperature in PBS containing $3 \%$ bovine serum albumin, $1 \%$ normal goat serum, and $0.4 \%$ Triton X-100. The slides were incubated with rabbit polyclonal anti-5- $\mathrm{HT}_{2 \mathrm{~A}}$ antibody $\left(1: 250\right.$, Neuromics) in blocking buffer for $48 \mathrm{~h}$ at $4{ }^{\circ} \mathrm{C}$, followed by addition of anti-MAP2 mouse monoclonal antibody (1:5000, Sigma), and further incubated overnight at $4{ }^{\circ} \mathrm{C}$. Slides were washed five times with PBS containing $0.4 \%$ Triton X-100; after that, goat anti-rabbit AlexaFluor488 and goat anti-mouse AlexaFluor-594 antisera $(1: 250$, Invitrogen, Eugene, OR) and Hoechst $3342(0.5 \mu \mathrm{g} / \mathrm{ml})$ were applied to slides for $1 \mathrm{~h}$ at room temperature. Fluorescent images were collected on a Nikon 80i Research Upright Microscope (Nikon, Tokyo, Japan) equipped with Surveyor Software with TurboScan (Objective Imaging, Kansasville, WI). Tiled images were collected with a Qimaging RetigaEXi camera (Qimaging, Surrey, BC, Canada). Separate images were collected for the $5-\mathrm{HT}_{2 \mathrm{~A}}$ receptor, nucleus (Hoechst), and MAP2 using either a $\times 10$ or $\times 20$ objective; these images were taken at 16-bit resolution (ie, 11000 by 15000 pixels). The relative distribution of the $5-\mathrm{HT}_{2 \mathrm{~A}}$ receptor was quantified using Imagej* software $(\mathrm{NIH})$. Raw images were corrected by subtracting the average intensity value of the background. Twelve regions of interest (ROIs), 200 by 200 pixels, were randomly selected for layer V and peripheral layers, the mean intensity was then measured for each ROI, and these were averaged for each brain section. The Hoechst and MAP2 staining were used as reference images.

Brain slice immunohistochemistry for biocytin and tryptophan hydroxylase was conducted to determine whether the neurons recorded from the $\mathrm{pet}^{+/+}$mice contained 5-HT as previously described (Beck et al, 2004). Slices from the pet $1^{-/-}$mice were also processed to detect expression of the lacZ marker of 5-HT precursor neurons as previously described (Scott et al, 2005), but using chicken anti- $\beta$-galactosidase (1:1000, Abcam) and FITC-conjugated goat anti-chicken $(1: 250$, Abcam) antibodies.

\section{Prepulse Inhibition of Acoustic Startle}

All prepulse inhibition (PPI) experiments were performed at the Mouse Behavioral Phenotyping Laboratory Core 
Facility in the Neurodevelopmental Disorders Research Center of UNC using the SR-Lab equipment (San Diego Instruments) as previously described (Abbas et al, 2009). Briefly, mice were placed in a small Plexiglas cylinder housed within a large sound-proofed chamber (San Diego Instruments). Each session consisted of a 5-min habituation period followed by 74 trials of 3 types - (1) no stimulation, (2) $120 \mathrm{~dB}$ acoustic stimulus (AS50), and (3) four different prepulse stimuli ranging from $4 \mathrm{~dB}$ over background (PP68) to $16 \mathrm{~dB}$ over background (PP78). PPI of acoustic startle was measured in the presence of a $64-\mathrm{dB}$ white-noise background. Mice were given three different types of trials. One trial type consisted of a $40 \mathrm{~ms} 120 \mathrm{~dB}$ white-noise startle stimulus. In the second, the startle stimulus was preceded by a $20-\mathrm{ms}$ prepulse stimulus that was $4,8,12$, or $16 \mathrm{~dB}$ above the white-noise background. In the third trial type, no auditory startle stimulus was presented, but only prepulse stimuli were presented, and these null trials served as controls for background movements by the animals. During testing, mice were acclimated to the apparatus for $5 \mathrm{~min}$ and then given 74 test trials. In 30 of the trials, the $120 \mathrm{~dB}$ stimulus was given alone (startle-only trials), whereas eight additional trials served as null trials. For the remaining 36 trials, the prepulse stimulus preceded the startle stimulus by $100 \mathrm{~ms}$. The behavioral responses were measured as the peak startle response for each trial between 35 and $65 \mathrm{~ms}$ after the onset of the startle stimulus. Inhibition of the startle response was calculated for each intensity of prepulse as the ratio of the prepulse trials to the startle-only trials subtracted from 1 and expressed as a percentage inhibition of response, that is, \% PPI $=[1$-(prepulse trials/startle-only trials) $]^{\star} 100$. For pharmacological studies, pet $1^{-/-}$mice and WT littermates were injected i.p. 30 min before PPI testing with vehicle (saline), clozapine $(0.5$ or $1.0 \mathrm{mg} / \mathrm{kg})$, and olanzapine $(0.5 \mathrm{mg} / \mathrm{kg})$.

\section{Locomotor and Stereotypic Activity}

Locomotor activity was assessed in photocell-based activity chambers under standardized environmental conditions, using an AccuScan activity monitor (AccuScan Instruments, Columbus, $\mathrm{OH}$ ) with a $25.8 \times 25.8 \mathrm{~cm}$ Plexiglas chamber and a beam spacing of $1.52 \mathrm{~cm}$ as described (Abbas et al, 2009). Mice were injected i.p. with vehicle, haloperidol $(0.1 \mathrm{mg} / \mathrm{kg})$, and clozapine $(0.5$ or $1.0 \mathrm{mg} / \mathrm{kg}) 30 \mathrm{~min}$ before PCP $(7.0 \mathrm{mg} / \mathrm{kg})$, followed by placement in the activity chambers. Activity data were collected for each mouse over $60 \mathrm{~min}$, beginning when the mouse was first placed in the testing chamber. Horizontal activity was measured as the total distance covered in centimeters as the total of all vectored X-Y coordinate changes. Stereotypy data were also collected in this automated fashion and calculated by these software packages based on contiguous breaks of the same single beam or a set of beams. Data are presented as total stereotypy counts, that is, number of repetitive beam breaks during $60 \mathrm{~min}$ of activity monitoring.

\section{Ligand Sets for SEA}

We extracted ligand sets from databases that annotate molecules by therapeutic or biological category (Keiser et al, 2009). For instance, the 2006.1 MDL Drug Data Report
(MDDR) contains 518 molecules annotated as $\alpha 1$ adrenergic receptor blockers, which we grouped into a single ' $\alpha 1$ adrenergic blocker' set. Three chemical databases provided these ligand sets: the ChEMBL 2009 (available from EMBLEBI, http://www.ebi.ac.uk/chembldb), the World of Molecular Bioactivity (WOMBAT) 2006.2 (Olah et al, 2004; Oprea et al, 2007), and the MDDR 2006.1 (MDL, now provided by Symyx) databases. For the ChEMBL and WOMBAT data sets, we organized ligands by their affinities, representing each protein target by three sets at 1 and $10 \mu \mathrm{M}$ cutoffs (as well as an additional $100 \mu \mathrm{M}$ cutoff for WOMBAT).

\section{Similarity Ensemble Approach (SEA)}

Clozapine, olanzapine, and haloperidol were computationally screened via SEA against a panel of 3725 protein targets. Each target was represented solely by its set of known ligands. We used both the 1024-bit folded ECFP4 (Hert et al, 2008) and 2048-bit daylight (James et al, 1992) fingerprints for SEA, as separate screens, and accepted the highestscoring predictions arising from either fingerprint. Because of the small size of the query data set (three drugs), all SEA predictions are reported here by $P$-values instead of by $E$-values (Keiser et al, 2009).

\section{Estimates of Number of Targets Screened}

We extracted 3725 targets for the cheminformatics screen from three databases: MDDR (246 targets), ChEMBL (2010 targets), and WOMBAT (1469 targets). However, there was appreciable target overlap across databases; we estimate that only 2250 of these targets are unique. To do so, we extracted accession numbers and UniProt IDs for each target and merged redundant targets via a synonym lookup table using UniProtKB/SwissProt and UniProtKB/TrEMBL database downloads (from http://www.uniprot.org, accessed 27 January 2010). We found 511 targets in common between ChEMBL and WOMBAT, leaving 1499 targets only found in ChEMBL and 536 targets only found in WOMBAT. Of the 536 WOMBAT-only targets, 296 did not have an accession number or UniProt ID; we excluded these from our counts to arrive at the lower-bounds estimate of 2250 unique cheminformatics targets. We determined by manual inspection that 162 of the 307 targets from the physical screen overlapped with the 2250-target cheminformatics screen. This yielded a final estimate of 2395 unique targets screened (Supplementary Table 3).

\section{Kinase Profiling and Checkpoint Kinase 2 Assay}

We profiled clozapine $(10 \mu \mathrm{M})$ activity on a set of 20 different kinases using Caliper Profiler Pro kinase assays and Labchip EZ reader according to the manufacturer's instruction (Caliper Life Sciences, Hopkinton, MA). The CHK2 activity assay was carried out in opaque 96-well plates using Omnia Kinase Assay Kit (Invitrogen, $\mathrm{KNZ1031).} \mathrm{The} \mathrm{assay} \mathrm{was} \mathrm{set} \mathrm{up} \mathrm{in} \mathrm{triplicate} \mathrm{in} \mathrm{a} \mathrm{final}$ reaction volume of $20 \mu \mathrm{l}$ per well containing $10 \mu \mathrm{M}$ of peptide substrate, $1 \mathrm{~mm}$ DTT, and varying concentrations of test drug or water to measure maximal kinase activity. Thereafter, $18 \mathrm{mU}$ of $\mathrm{CHK} 2$ enzyme protein (Invitrogen no. 
PV3367) was added to each well and the plate was loaded immediately into a FlexStation II reader (Molecular Diagnostics) at $30^{\circ} \mathrm{C}$, mixed for $5 \mathrm{~s}$, and read (excitation at $360 \mathrm{~nm}$ and emission at $485 \mathrm{~nm}$ ) every $30 \mathrm{~s}$ for the next $60 \mathrm{~min}$. Plateau readings at the $30 \mathrm{~min}$ point were processed and analyzed to calculate $\mathrm{IC}_{50}$ of tested compounds using GraphPad Prism 5.0.

\section{Statistical Analysis}

For quantitation of immunoblots, comparison of $B_{\max }$ data, and other two-group comparisons, two-tailed unpaired $t$-tests were used to ascertain statistical significance. All behavioral data were analyzed by two-way ANOVA followed by Bonferroni post tests for comparing multiple groups. Comparisons were considered significant if $p$-value was $<0.05$.

\section{RESULTS}

\section{Clozapine Interacts with a Defined Subset of Molecular Targets}

Because the molecular target(s) responsible for clozapine's actions remain controversial, we initially utilized an unbiased physical screening approach in which clozapine and selected typical and atypical antipsychotic drugs were profiled against all known molecular targets implicated in antipsychotic drug actions. The targets interrogated included both validated antipsychotic drug targets (eg, D2, D3 dopamine; $5-\mathrm{HT}_{2 \mathrm{~A}}$ serotonin) as well as most of the currently investigated targets (eg, M1, M4 muscarinic; mGluR2/3 metabotropic glutamate; nicotinic acetylcholine) (Conn and Roth, 2008; Gray and Roth, 2007; Jensen et al, 2008). We then performed hierarchical clustering analysis to identify atypical antipsychotic drugs that were most similar to clozapine and typical antipsychotic drugs that were most dissimilar. As shown in Figure 1a, olanzapine was the most similar atypical antipsychotic drug to clozapine, whereas haloperidol was the most dissimilar typical antipsychotic drug. We then chose clozapine, olanzapine, and haloperidol for further study.

The 'druggable genome,' of which the receptorome (Armbruster and Roth, 2005), the kinome (Manning et al, 2002), enzymes, and other 'druggable' targets (Hopkins and Groom, 2002) are part, is estimated to represent perhaps 2300 distinct molecular targets (Hopkins and Groom, 2002). Although it is not currently technically feasible to obtain the activity profile of clozapine at every conceivable druggable target, we have been able to achieve satisfactory coverage of these druggable targets falling into the GPCR, kinase, transporter, ion channel, and enzyme classes. To investigate whether there might be other likely targets, not available among these readily screenable targets, we used our newly validated computational SEA (Keiser et al, 2007; Keiser et al, 2009) to screen all three drugs against a panel of $\sim 2250$ molecular targets, all of which have annotated ligands. These calculations also allowed us to investigate the similarities and differences in target association among the three drugs; we were particularly interested to see whether clozapine and olanzapine associated with similar targets, and whether these differed substantially from the targets with which SEA predicted haloperidol to associate (Supplementary Table 1). SEA predicted only one new target for clozapine, farnesyl protein transferase (PFTase, Supplementary Table 1). The SEA predictions suggested new targets for olanzapine, such as the $5-\mathrm{HT}_{3 \mathrm{~A}}$ serotonin receptor (HTR3A; likelihood of random association, $P$-value, $1.09 \times 10^{-10}$ ), the $5-\mathrm{HT}_{3 \mathrm{~B}}$ serotonin receptor (HatAR3B; $P$-value $1.18 \times 10^{-8}$ ), the H4 histamine receptor (HRH4; $P$-value $3.69 \times 10^{-8}$ ), and UDP-glucuronosyltransferase 1A4 (UGT1A4, $P$-value $1.63 \times 10^{-18}$; Supplementary Table 1). In each of these cases, the olanzapine-predicted target is a known target of clozapine that is neither predicted for nor known to interact with haloperidol. However, upon inspection, each of these targets is already reported to be a target for olanzapine in KiDB, whereas UGT1A4 is known to directly glucuronidate olanzapine (Linnet, 2002). Except for PFTase ( $P$-value $\left.2.46 \times 10^{-5}\right)$, none of the predicted targets differs greatly from those that both drugs were already known to modulate.

We next physically interrogated a large portion of the druggable genome to determine if there could be additional targets for clozapine that were not predicted by SEA. Figure $1 \mathrm{~b}$ shows the combined results obtained from our queries of internally derived physical screening campaigns from the NIMH-PDSP as well as the publicly available physical screening campaigns extracted from the PubChem database (see Supplementary Table 2 for the complete data set) at $>300$ target-based assays. As shown in Figure $1 \mathrm{~b}$ and Supplementary Table 2, clozapine and olanzapine differed from haloperidol by virtue of their high-affinity interactions with most of the 14 human serotonin GPCRs and relatively lower affinity interactions with D2, D3, and D4 dopamine receptors. Furthermore, Figure 2a shows the lack of activity of clozapine at various protein kinases implicated in psychotherapeutic drug actions (eg, GSK3 $\beta$, Erk1, Erk2, and Akt1) (Beaulieu et al, 2009; Beaulieu et al, 2008; Beaulieu et al, 2005). In passing, we note that clozapine was a moderately potent inhibitor of CHK2 (Figure 2b) - a kinase involved in cell cycle regulation (Matsuoka et al, 1998).

\section{The Presynaptic Component of Serotonin Neurons Is Essential for Clozapine's Ability to Normalize the NMDA-Receptor Hypofunction Characteristic of Schizophrenia}

The results of Figure 1 suggested to us that the most likely locus of clozapine's actions was engagement of the serotonergic neuronal system. Because many serotonin receptors are both pre- and post-synaptic with respect to serotonin neurons, it was not clear whether the requirement for serotonergic engagement would be pre- or postsynaptic, although current hypotheses posit a selective effect of clozapine on postsynaptic serotonin receptors (eg, HTR2A, HTR2C, HTR6, and HTR7; Conn and Roth, 2008; Roth et al, 2004). These hypotheses predict that deletion of the presynaptic component of the serotonin neuronal system would not affect clozapine's therapeutic actions. To test these hypotheses, we took advantage of the observation that the ETS-domain transcription factor pet 1 is essential for normal expression of the serotonergic phenotype in neurons, and that its deletion greatly 

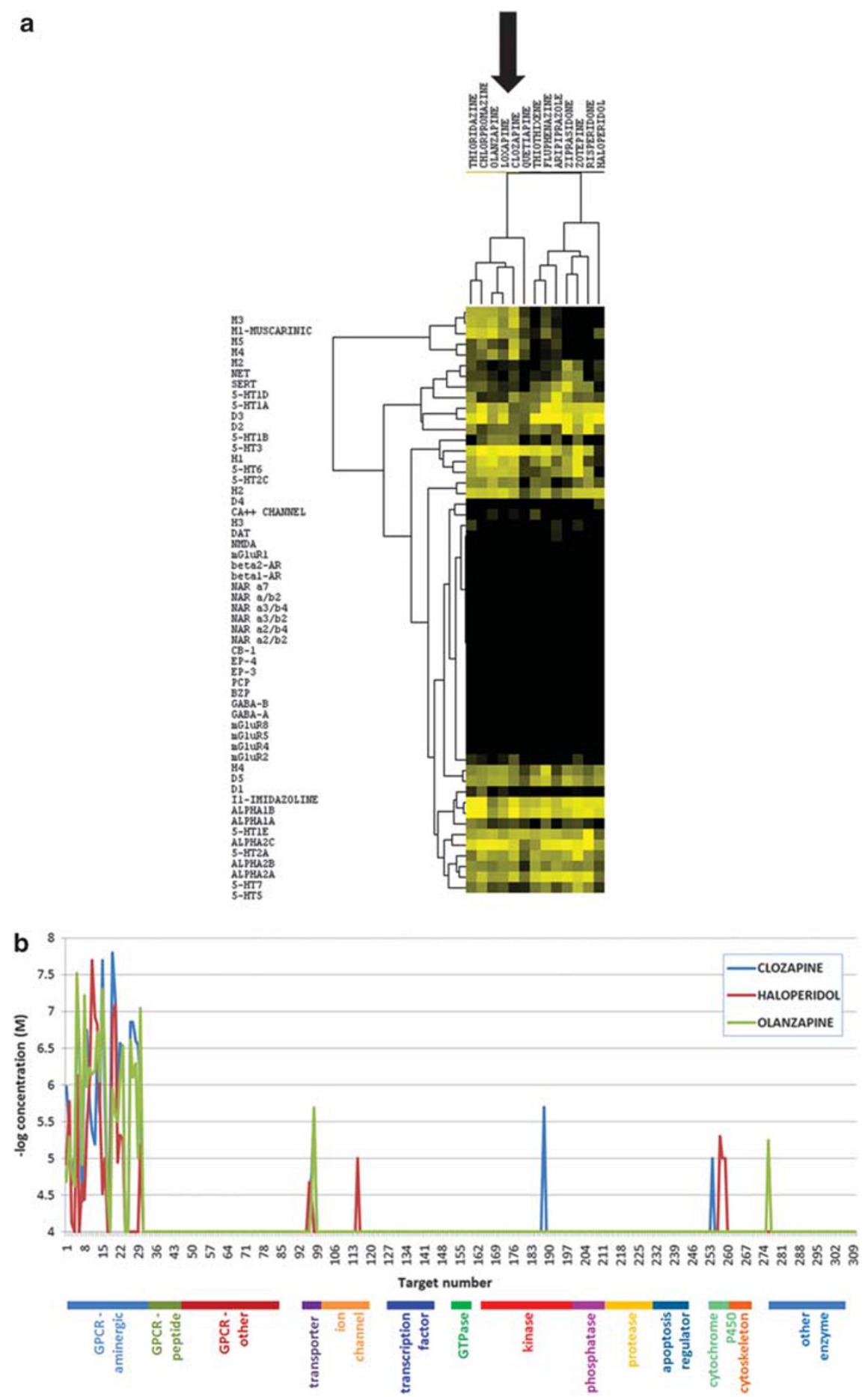

Figure I Mining the druggable genome identifies molecular targets for clozapine action. (a) Results from hierarchical clustering analysis of affinities of approved typical and atypical antipsychotic drugs at molecular targets implicated in antipsychotic drug action (Gray and Roth, 2007; Roth et al, 2004). See Supplementary Table 2 for complete data set. Arrow indicates location of node specifying clozapine and olanzapine. (b) Summary results from an interrogation of clozapine, olanzapine, and haloperidol at $>300$ distinct molecular targets (see Supplementary Table 2 for complete data set).

diminishes expression of presynaptic serotonergic markers (Hendricks et al, 2003; Jensen et al, 2008; Scott et al, 2005).

For initial studies, we examined the ability of clozapine to normalize the disruption of PPI induced by the noncompetitive NMDA-receptor antagonist phencyclidine (PCP). We chose PCP because it is known to induce a psychotic state that reliably mimics both the positive and negative symptoms of schizophrenia in humans (Javitt and Zukin, 1991). Disrupted PPI is also well established and validated as a measure of the impaired sensory-motor gating characteristic of schizophrenia (Geyer and Braff, 1987; Mansbach and Geyer, 1989). Importantly, atypical antipsychotic drugs like clozapine are unique in their ability to normalize PCP-induced disruption of PPI (Bakshi 

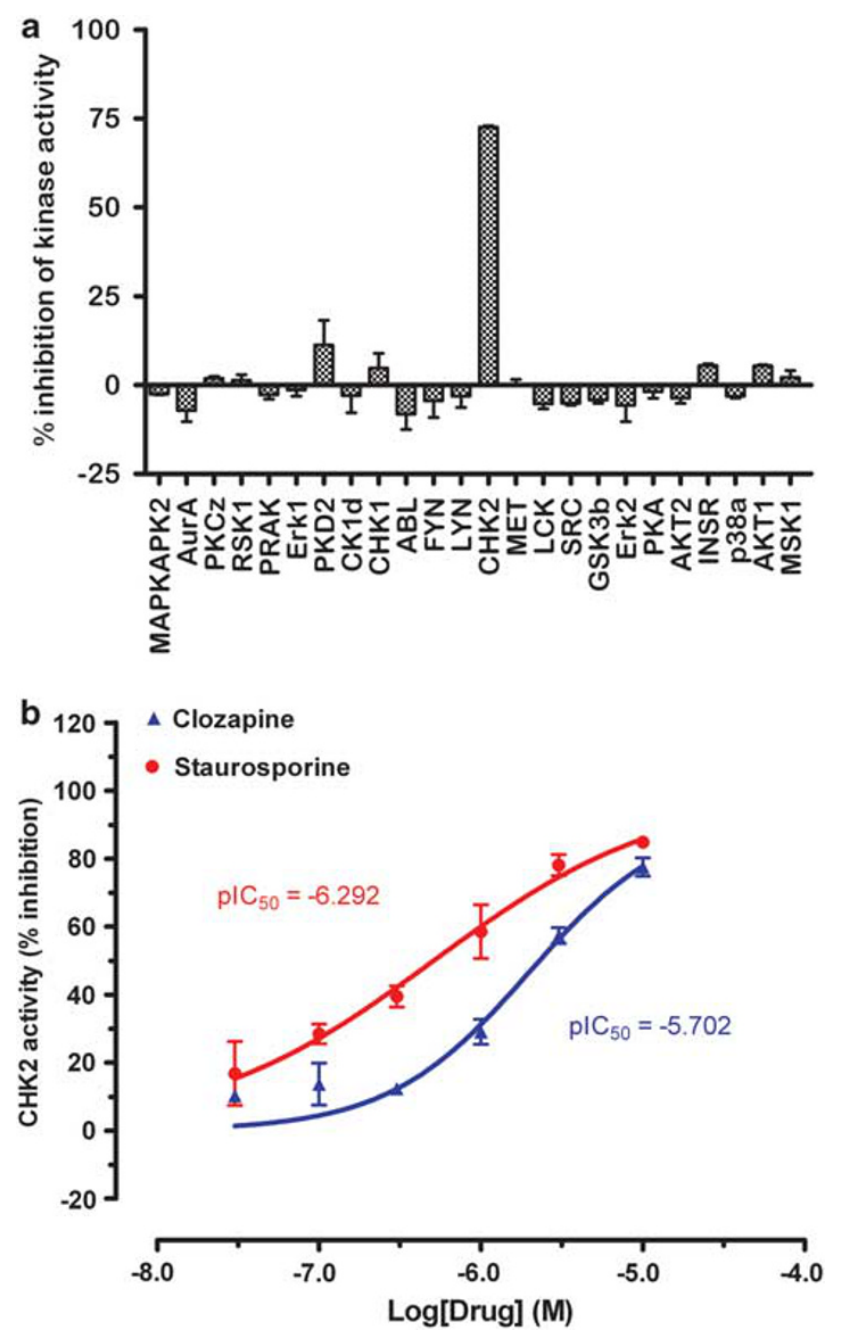

Figure 2 Kinase profiling reveals activity of clozapine only at checkpoint kinase 2 (ChK2). (a) Shown are results from a kinase profile performed with a Caliper microfluidics-based screening platform (part no. 760373) that comprises 20 different purified kinases. Clozapine $(10 \mu \mathrm{M})$ was tested against all the kinases shown above and data are presented as \% inhibition of kinase activity. (b) Dose-response studies with clozapine and the nonspecific kinase inhibitor staurosporine at Chk2. Data represent mean \pm error of $N=3$ separate determinations. $E_{50}$ values determined using GraphPad Prizm.

et al, 1994). As is shown in Figure 3a, acute administration of PCP induced a marked disruption of PPI in both pet $1^{-/-}$ and pet $^{+/+}$littermate control mice. Significantly, clozapine normalized PCP-disrupted PPI in pet $1^{+/+}$but not in pet $^{-1-}$ mice (Figure 3a). To determine if these results were unique to clozapine, we tested olanzapine as well, because it most closely mimics the polypharmacological profile of clozapine. As shown in Figure 3b, olanzapine normalized PCP-disrupted PPI in pet $1^{+/+}$but not in pet $1^{-1-}$ mice. These results indicate that genetic deletion of pet 1 abolishes the ability of both clozapine and olanzapine to normalize NMDA-receptor hypofunctioning. Therefore, the actions of clozapine and olanzapine depend on the presynaptic component of the serotonergic neuronal system. We also examined the ability of clozapine to normalize the PCP-induced enhancement of locomotor activity and stereotypy. As shown in Figures $3 c$ and $d$ and 4, PCP induced a significant enhancement of locomotor behavior and stereotypical movements, which were normalized by clozapine in pet $1^{+/+}$(Figure $3 \mathrm{c}$ ) but not in pet $1^{-/-}$ (Figure 3d) mice. As an essential control, we show that the typical antipsychotic haloperidol normalized locomotor behavior and stereotypy in both pet $1^{+/+}$and pet $1^{-/-}$mice (Figures $3 \mathrm{e}, \mathrm{f}$ and $4 \mathrm{a}$ ) - a result predicted based on its relatively selectively potent interaction with D2-family dopamine receptors, in contrast to the profiles of clozapine or olanzapine, which more preferentially target $5-\mathrm{HT}$ receptors.

Given these results, we wondered if genetic deletion of $5-\mathrm{HT}_{2 \mathrm{~A}}$ serotonin receptors, which have been proposed to mediate many of clozapine's unique actions (Meltzer et al, 1989), might phenocopy pet 1 deletion, at least with respect to clozapine's antipsychotic-like actions. Accordingly, we examined the ability of clozapine to normalize PCP-induced disruption of PPI in $5-\mathrm{HT}_{2 \mathrm{~A}}^{+1+}$ and $5-\mathrm{HT}_{2 \mathrm{~A}}^{-1-}$ mice. As shown in Figure $4 \mathrm{~b}$, clozapine normalized PCP-induced PPI disruption in both $5-\mathrm{HT}_{2 \mathrm{~A}}^{-1-}$ and WT littermate control mice. We also noted that $5-\mathrm{HT}_{2 \mathrm{~A}}^{+1+}$ and $5-\mathrm{HT}_{2 \mathrm{~A}}^{-1-}$ mice were generated on the $129 \mathrm{~S}$ background strain and displayed a diminished sensitivity to clozapine. We performed dose response with clozapine (data not presented) in these mice, and the data with the lowest effective doses of clozapine in $5-\mathrm{HT}_{2 \mathrm{~A}}^{-1-}$ and WT littermates are shown in Figure $4 \mathrm{~b}$. These results indicate that postsynaptic $5-\mathrm{HT}_{2 \mathrm{~A}}$ receptors are not essential for mediating clozapine's ability to normalize PCPinduced disruption of sensory-motor gating in vivo.

Given these results, we wondered if one possible explanation for the inability of clozapine to normalize behavioral measures of NMDA-receptor hypofunction could be that genetic disruption of pet 1 has altered the cellular expression and/or sensitivity of postsynaptic $5-\mathrm{HT}_{2 \mathrm{~A}}$ serotonin receptors. To address this possibility, we measured cortical $5-\mathrm{HT}_{2 \mathrm{~A}}$ receptor protein levels via western blot, ${ }^{3} \mathrm{H}$-ketanserin radioligand binding, and immunofluorescence analysis. We found equivalent amounts of $5-\mathrm{HT}_{2 \mathrm{~A}}$ receptor protein, radioligand binding (Figure $5 \mathrm{a}-\mathrm{c}$ ), and a similar cellular and subcellular distribution of $5-\mathrm{HT}_{2 \mathrm{~A}}$ receptors in pet $1^{+/+}$and pet $1^{-/}$mice (Figure $5 \mathrm{~d}$ and e). To determine if a change in postsynaptic $5-\mathrm{HT}_{2 \mathrm{~A}}$ receptor sensitivity was present in pet $1^{-/-}$mice, we evaluated DOIinduced head-twitch and pERK responses in pet1 ${ }^{+/+}$and pet $1^{-1-}$ mice, as previously described (Abbas et al, 2009). As can be seen in Figure $5 \mathrm{f}-\mathrm{h}$, DOI-induced responses were augmented in pet $^{-\gamma-}$ mice, as might be expected given the loss of presynaptic 5-HT innervations seen in pet $1^{-/-}$mice. We also determined the $5-\mathrm{HT}_{2 \mathrm{C}}$ expression level in hippocampus, as clozapine has affinity for this receptor, and found significantly increased $5-\mathrm{HT}_{2 \mathrm{C}}$ expression in hippocampus of pet1 $1^{-1-}$ mice in comparison with WT littermate controls (Supplementary Figure 1). Furthermore, the antipsychotic-like properties of M100907 (5- $\mathrm{HT}_{2 \mathrm{~A}}$ selective antagonist) and MK212 (5- $\mathrm{HT}_{2 \mathrm{C}}$ selective agonist) for normalizing the PCP-induced disruption of PPI is selectively blunted in pet $1^{-1-}$ mice (Supplementary Figures 2 and 3 ). These results indicate that the inability of atypical antipsychotic drugs to normalize NMDAreceptor hypofunction in pet $1^{-1-}$ mice is not because of $5-\mathrm{HT}_{2 \mathrm{~A}}$ or $5-\mathrm{HT}_{2 \mathrm{C}}$ postsynaptic receptor insensitivity. 

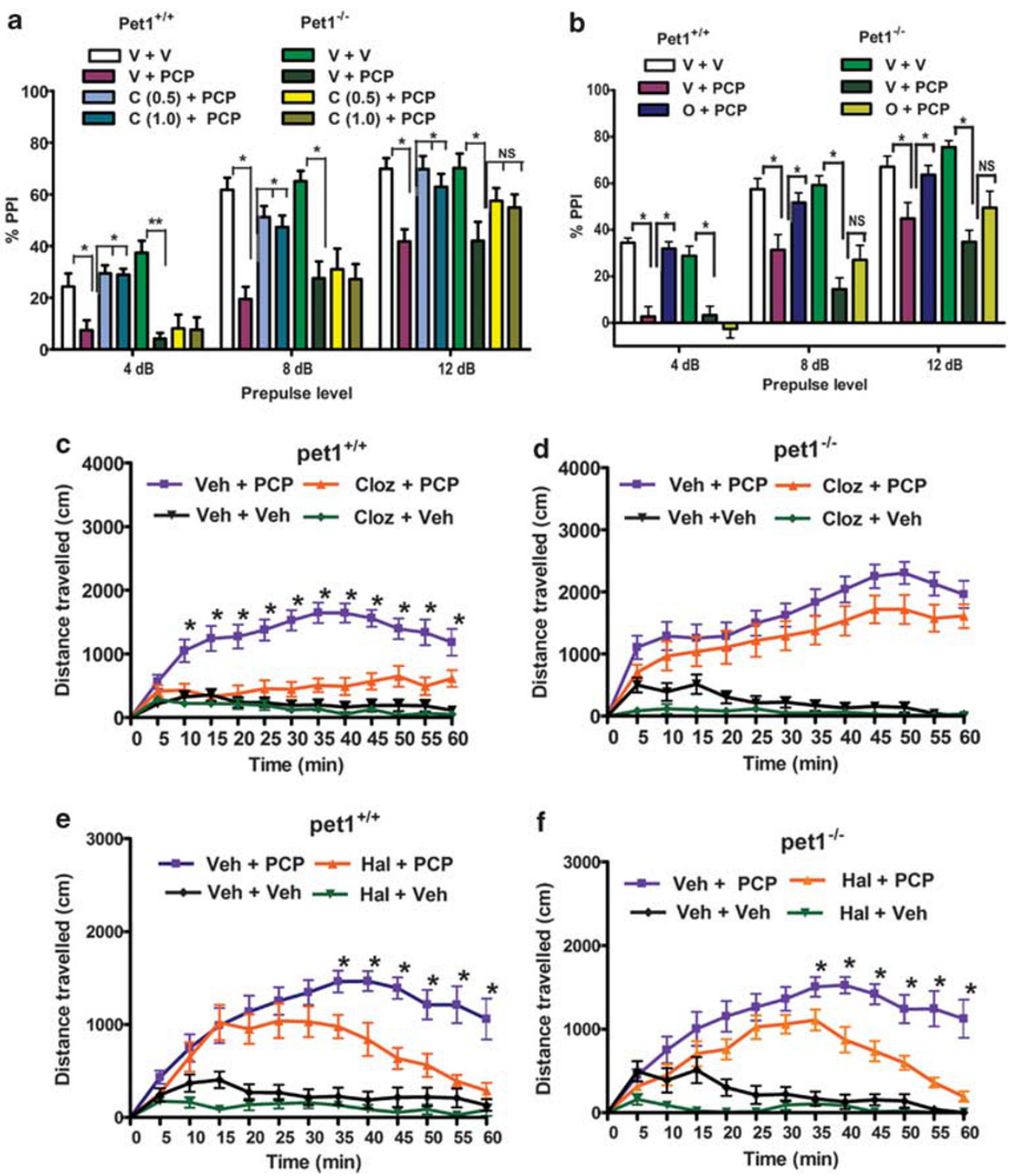

Figure 3 The presynaptic component of serotonin neuronal system is required for clozapine's therapeutic actions in vivo. (a) Effect of clozapine (C, $0.5 \mathrm{mg} / \mathrm{kg}$ or $1.0 \mathrm{mg} / \mathrm{kg}$ ) on PCP $\left(7.0 \mathrm{mg} / \mathrm{kg}\right.$ )-induced disruption of prepulse inhibition (PPI) was measured. In pet ${ }^{+/+}$mice, clozapine pretreatment completely normalized disruption of PPI by PCP at all prepulse levels, whereas it had no effect on pet $I^{-1-}$ mice $(N=16 / g r o u p)$. (b) Effect of olanzapine $(O, 0.5 \mathrm{mg} / \mathrm{kg})$ on PCP $(7.0 \mathrm{mg} / \mathrm{kg})$-induced disruption of PPI was measured. Similar to clozapine, olanzapine also did not exhibit any significant effect on PCPinduced PPI deficit in pet $I^{-1-}$ mice. (c, d) Pretreatment $(30 \mathrm{~min}$ ) with clozapine $(0.5 \mathrm{mg} / \mathrm{kg})$ significantly blocked PCP $(7.0 \mathrm{mg} / \mathrm{kg})$-induced hyperactivity in

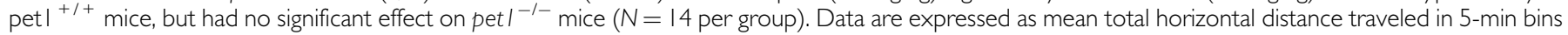
over 60 min after PCP administration ( \pm SEM). (e, f) Haloperidol (Hal, $0.1 \mathrm{mg} / \mathrm{kg}$ ) significantly attenuated PCP-induced hyperactivity in both genotypes $(N=12$ per group). Data are expressed as mean total horizontal distance traveled over $60 \mathrm{~min}$ in 5 -min bins after PCP administration $( \pm S E M)$. * $p<0.05$, two-way ANOVA followed by Bonferroni post tests for multiple comparisons.

It has also been suggested that clozapine-like drugs exert their effects principally via direct (or indirect) activation of $5-\mathrm{HT}_{1 \mathrm{~A}}$ serotonin receptors (Newman-Tancredi et al, 1998; Rollema et al, 1997). It is conceivable, therefore, that a diminution of $5-\mathrm{HT}_{1 \mathrm{~A}}$ receptor number and/or sensitivity could exist in mice with a genetic deletion of pet1. To address this possibility, we quantified cortical $5-\mathrm{HT}_{1 \mathrm{~A}}$ receptors via ${ }^{3} \mathrm{H}-$ WAY 100635 radioligand binding and found that pet $1^{-1-}$ mice showed more (not less) ${ }^{3} \mathrm{H}-$ WAY100635 binding than pet $1^{+/+}$mice in the cortex and hippocampus (Figure 6a). We also examined the electrophysiological properties of $5-\mathrm{HT}_{1 \mathrm{~A}}$ receptors in hippocampal slices from pet $1^{+/+}$and pet $1^{-/-}$mice and found, as would be expected from the binding data, a significantly exaggerated response in pet $1^{-1}$ when compared with $\mathrm{pet}^{+9+}$ mice (Figure $6 \mathrm{~b}$ and c). Taken together, these results indicate that clozapine's inability to rescue NMDAreceptor hypofunctioning is not because of diminished forebrain $5-\mathrm{HT}_{1 \mathrm{~A}}$ receptor expression or activity.

Finally, and most critically, we interrogated the physiological function of the presynaptic component of the serotonin neuronal system to verify its relative ablation in pet $1^{-1-}$ mice. We first utilized the psychotomimetic agent methylene-dioxy-methamphetamine (MDMA) that induces locomotion via a presynaptic release of 5-HT. As shown in Figure $7 \mathrm{a}$ and $\mathrm{b}$, the locomotor effects of MDMA were 
abolished in pet $^{-/-}$mice. We next tested the presynaptic $5-\mathrm{HT}_{1 \mathrm{~A}}$ receptor-mediated response electrophysiologically in midbrain raphe slices from pet $1^{+/+}$and pet $1^{-1-}$ mice. The magnitude of the 5- $\mathrm{HT}_{1 \mathrm{~A}}$ hyperpolarization recorded from the pet 1 knockout mice was significantly less, and 14 out of the 24 neurons recorded demonstrated no response at all, as shown in Figure 7c and d. In contrast, the responses recorded from the pet 1 wild-type mice were normal in magnitude (Figure $7 \mathrm{c}$ and $\mathrm{d}$ ). These results confirm a functional ablation of the presynaptic component of the serotonergic neuronal system in pet ${ }^{-1-}$ mice. Taken together, these results demonstrate that an intact presynaptic component of the 5-HT neuronal system is essential for clozapine's actions.

\section{DISCUSSION}

In this paper, we identify the presynaptic component of the serotonin neuronal system as an essential mediator of atypical antipsychotic drug action in vivo. Although literally thousands of studies have been published regarding clozapine's actions, the molecular substrates essential for its unique effects remain intensely controversial. Indeed, previous studies have demonstrated that clozapine and related atypical antipsychotic drugs have preferentially high affinity for postsynaptic $5-\mathrm{HT}_{2 \mathrm{~A}}$ serotonin (Meltzer et al, 1989), D4 dopamine (Van Tol et al, 1991), muscarinic acetylcholine (Miller and Hiley, 1974), as well as dozens of other GPCRs (Roth et al, 2004). Indeed, each of these
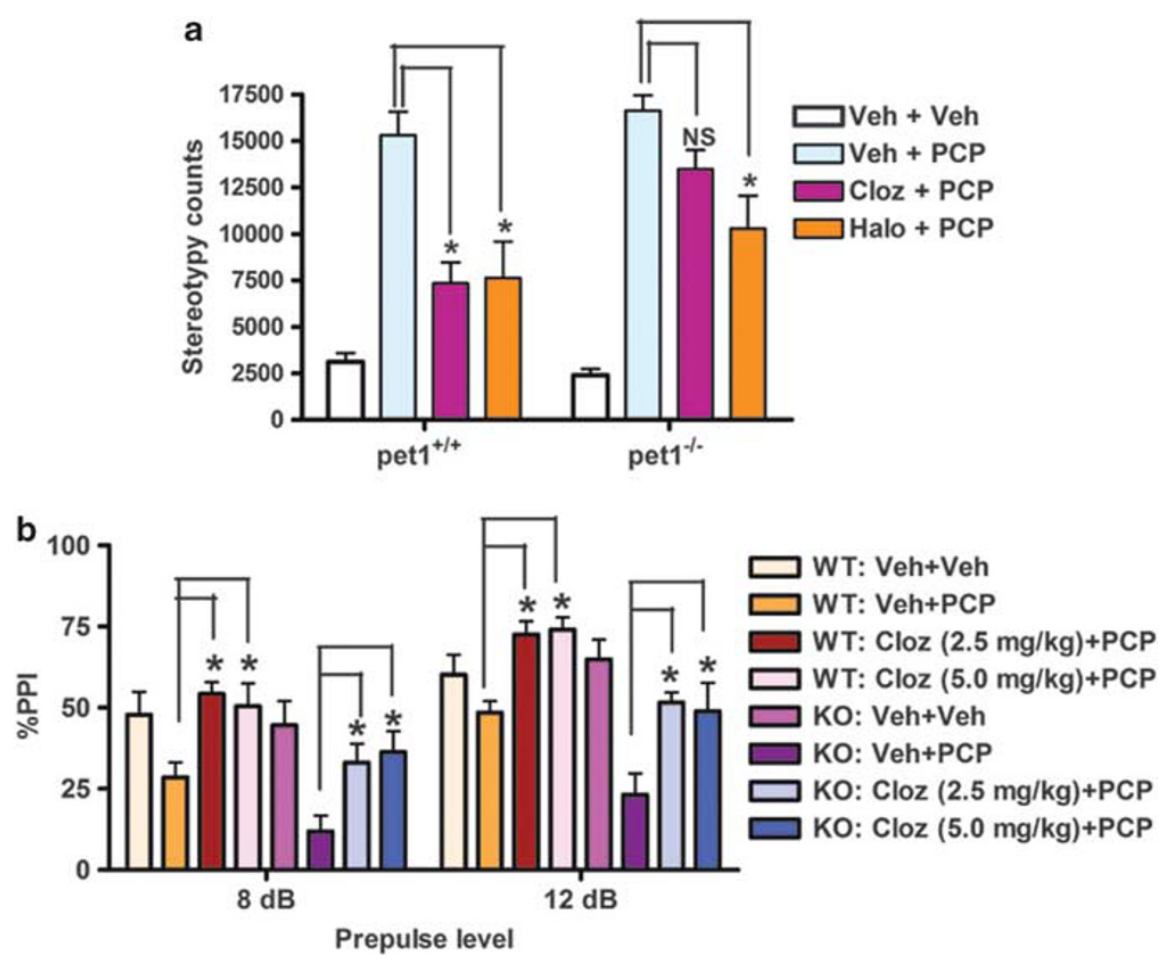

Figure $45-\mathrm{HT}_{2 \mathrm{~A}}$ receptor is not essential for clozapine's antipsychotic drug actions. (a) Pretreatment (30 min) with clozapine $(0.5 \mathrm{mg} / \mathrm{kg})$ significantly blocked PCP $(7.0 \mathrm{mg} / \mathrm{kg})$-induced stereotypy in pet $1^{+1+}$ mice, but had no significant effect on pet $I^{-1-}$ mice $(\mathrm{N}=8$ per group). However, haloperidol $(0.1 \mathrm{mg} / \mathrm{kg})$ significantly attenuated PCP-induced stereotypy in both group of mice. Data are expressed as mean total stereotypy counts in 60 min after PCP administration ( \pm SEM). ${ }^{*} p<0.0$ I, two-way ANOVA followed by Bonferroni post test for multiple comparisons. NS, not significant. (b) Clozapine normalizes the PCP induced PPI deficit in 5-HT2A KO mice. Effect of clozapine on PCP $(7.0 \mathrm{mg} / \mathrm{kg})$-induced disruption of prepulse inhibition (PPI) was measured. Clozapine pretreatment ( $30 \mathrm{~min}$ ) completely normalized disruption of PPI by PCP in both WT and KO mice ( $N=8$ per group). * $p<0.0$ I, twoway ANOVA followed by Bonferroni post test for multiple comparisons.

Figure 5 Postsynaptic supersensitivity of $5-\mathrm{HT}_{2 \mathrm{~A}}$ receptors following deletion of petl. (a) Immunoblot of WGA immunoprecipitates from cortex membrane lysate of two representative pet- $I^{-1-}$ and pet $I^{+/+}$littermate pairs. The same blots were stripped and probed for transferrin receptor as loading controls. (b) Densitometry of immunoblots of WGA IP from five pairs of WT and pet $I^{-1-}$ mice. (c) $B_{\max }$ estimates were obtained by performing $\left.{ }^{3} \mathrm{H}\right]$ ketanserin saturation binding on DLFC membrane homogenates. Data are presented as mean $\pm \mathrm{SEM}$ ( $N=5$ per group). (d) $5-\mathrm{HT}_{2 A}$ receptor (green, top and bottom panels) and MAP2 (red) immunochemistry in coronal sections of a pet $I^{-1-}$ and pet ${ }^{+/+}$littermate pair. Middle panel is overlay of 5-HT2A (green), MAP2 (red), and Hoechst (blue) immunostaining to compare the distribution of 5- $\mathrm{HT}_{2 \mathrm{~A}}$ receptors between dendrites and cell bodies. (e) Estimates of 5- $\mathrm{HT}_{2 \mathrm{~A}}$ receptor abundance by immunofluorescence in layer $\mathrm{V}$ and in peripheral layers. 12 regions of interest (ROls), 200 by 200 pixels, were randomly selected for both layer $\vee$ and the peripheral layers. The mean intensity was then measured for each $\mathrm{ROI}$ and these were averaged for each brain section ( $\mathrm{N}=3$ per genotype). (f) $5-\mathrm{HT}_{2 \mathrm{~A}}$-mediated signaling is potentiated in pet $\mathrm{I}^{-1-}$ mice. Representative immunoblot of DOI (5.0 mg/kg, i.p. $\left.15 \mathrm{~min}\right)$-induced pERKI/2 and total ERKI/2 (as loading control) in microdissected cortical lysates. (g) Densitometry of DOI-induced pERKI/2 immunoblots; data are expressed as \% vehicle (veh), $N=5$ to 6 per group, $* p<0.05$, one-way ANOVA followed by Neuman-Keuls post hoc analysis for multiple comparisons. (h) $\mathrm{DOI}(0.5-5.0 \mathrm{mg} / \mathrm{kg})$-induced head twitches were counted as measure of hallucinogenic activity; data are expressed as mean \pm SEM $(N=6-8$ per group, ${ }^{*} p<0.05$, ${ }^{* *} p<0.0$ l; unpaired $t$-test). 
individual molecular targets to which clozapine binds with high affinity has been subsequently exploited for drug discovery purposes. Drugs that have been developed that attempt to mimic clozapine's actions by selectively targeting these 'clozapine receptors' have all failed to be approved as efficacious treatments of schizophrenia. This spectacular drug discovery failure prompted us to re-examine the molecular and neuronal substrates responsible for clozapine's actions in vivo.

To comprehensively and in an unbiased fashion identify all the potential site(s) of action of clozapine, we initially screened a representative sample of known typical and
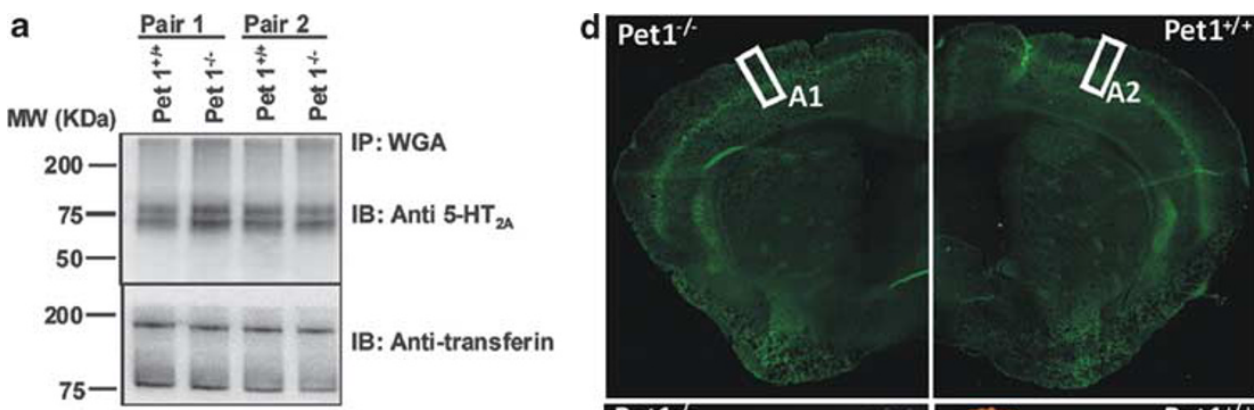

b
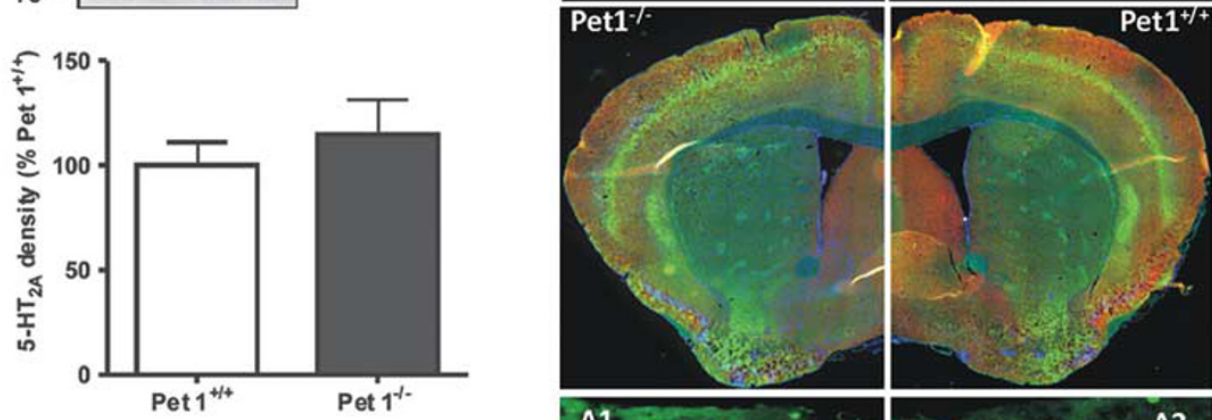

C
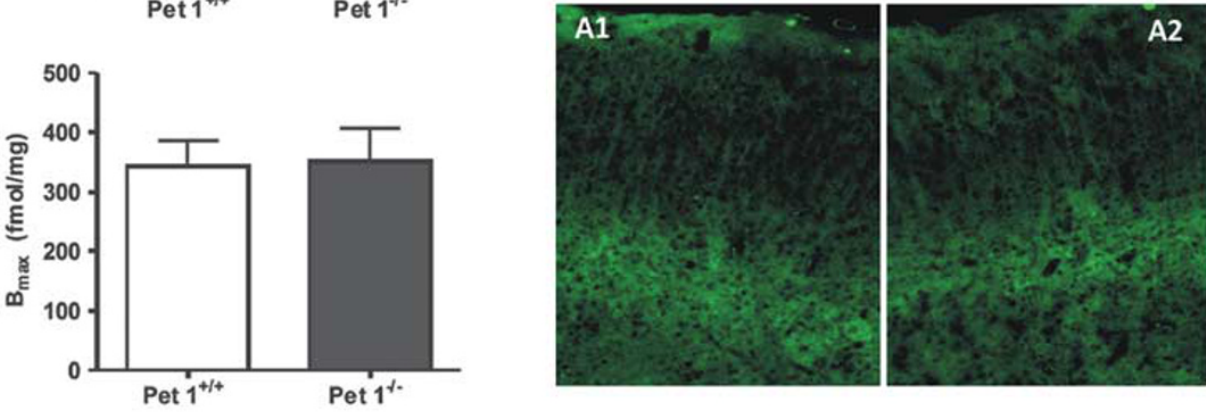

$\mathbf{f}$

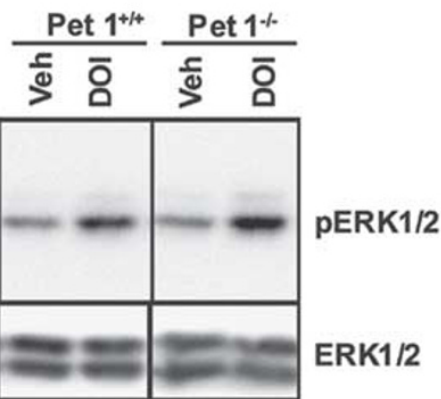

e
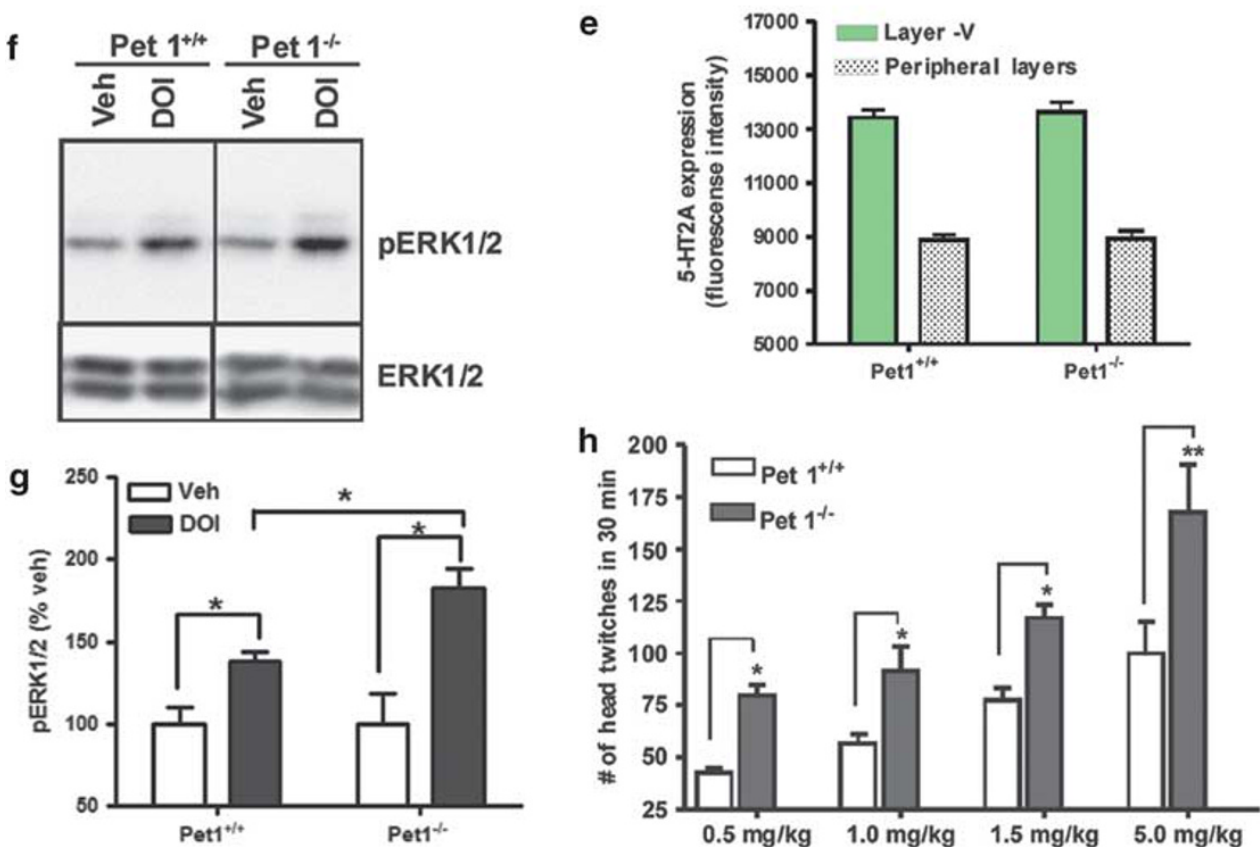
atypical antipsychotic drugs against a panel of known molecular targets implicated in antipsychotic drug actions. Hierarchical clustering revealed that clozapine and olanzapine were most similar to each other among approved atypical antipsychotic drugs, and were very distinct from haloperidol. We then evaluated these three drugs against $>300$ distinct molecular targets to gain satisfactory physical screening coverage of the 'druggable genome' (Hopkins and Groom, 2002). We discovered that clozapine and olanzapine differed from haloperidol mainly by virtue of high affinities for nearly all known 5-HT receptors. In passing, we noted that clozapine and olanzapine were weak inhibitors of Chk2 - a checkpoint kinase - although the potencies of clozapine and olanza-

a

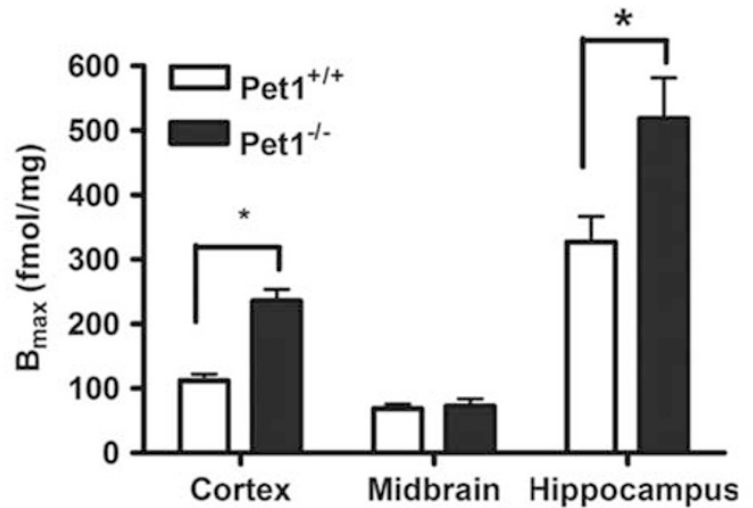

b
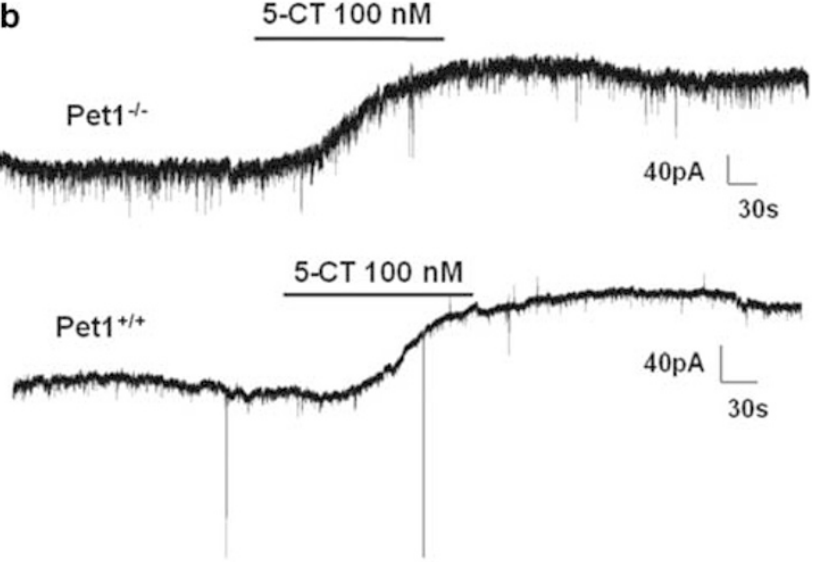

C

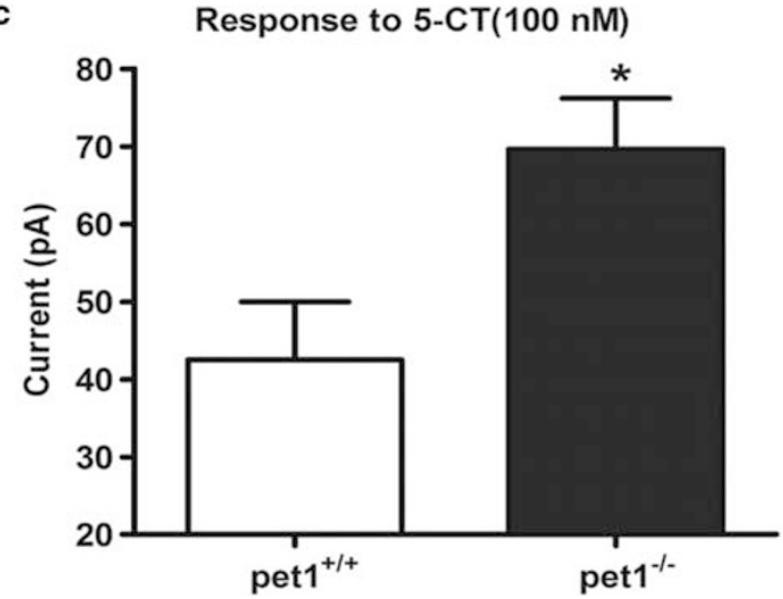

pine for Chk2 $(\sim 10 \mu \mathrm{M})$ are probably too low to be of therapeutic relevance. One unique class of druggable targets represented in our screen are the orphan GPCRs. Despite screening 26 of these orphans, we have failed to identify unique clozapine targets among them (data not shown). Efforts are ongoing to screen all $160+$ orphan GPCRs as potential clozapine targets (WK Kroeze and BL Roth, unpublished).

To cast an even wider net, we also employed a new and unbiased computational method, the SEA, to identify possible targets for these three drugs beyond the panel of targets explicitly screened (Keiser et al, 2007; Keiser et al, 2009). SEA predictions predominantly recapitulated the known targets of these drugs, and even where new and previously uncharacterized targets were suggested for olanzapine, these had already been characterized for clozapine. Indeed, clozapine and olanzapine often shared predicted targets by SEA-primarily aminergic GPCRs - with which haloperidol was not predicted to associate. Combining the 307 targets interrogated from the physical screening campaign and the 2250 targets from the SEA screen, we have interrogated over 2350 targets by a combination of these two methods. Taken together, these results indicate that the three drugs evaluated interact mainly with known biogenic amine receptors, and that the probability is low that any additional druggable targets exist that could account for the unique actions of clozapine.

Given the preferentially high affinity of clozapine and olanzapine for most known 5-HT receptors, we postulated that the serotonergic neuronal system is required for clozapine's action. Indeed, for decades, it has been suggested, without confirmatory studies using knockout mice, that 5-HT and its receptors are key mediators of clozapine's actions (Fink et al, 1984; Carlsson et al, 1999). Here, we took advantage of the observation that genetic deletion of pet 1 results in a generalized loss of 5-HT and the presynaptic component of the serotonin neuronal system (Hendricks et al, 2003). This diminution of brain serotonin led to an enhancement in $5-\mathrm{HT}_{2 \mathrm{~A}}, 5-\mathrm{HT}_{2 \mathrm{C}}$, and $5-\mathrm{HT}_{1 \mathrm{~A}}$ responses. However, despite this apparent postsynaptic supersensitivity, we found that deletion of pet1 abolished clozapine's efficacy. Importantly, we also found that genetic deletion of $5-\mathrm{HT}_{2 \mathrm{~A}}$ receptors - heretofore considered the main target implicated in clozapine's actions - only marginally attenuated clozapine's antipsychotic-like actions. Instead, these present findings implicate the presynaptic component of the 5-HT neuronal system as being essential for clozapine's unique actions.

\footnotetext{
Figure 6 Upregulation and supersensitization of postsynaptic $5-\mathrm{HT}_{\text {IA }}$ receptors in pet $I^{-1-}$. (a) Comparison of $5-H_{T} T_{A}$ expression $\left(B_{\max }\right.$ estimates) in cortex, midbrain, and hippocampus. $B_{\max }$ values were obtained by $\left[{ }^{3} \mathrm{H}\right]$-WAY 100635 saturation binding, and data are presented as mean \pm SEM ( $N=5$ to 6 per genotype). $* p<0.05$, unpaired $t$-test. (b, c) 5-CT-induced changes in whole-cell current in CAI pyramidal neurons. (a) Representative chart recordings of current elicited by bath application of 5-CT. All cells were recorded in voltage clamp mode with cells held at $-60 \mathrm{mV}$; length of line above each chart depicts the amount of time the drug was in chamber. (b) Graphical presentation of whole-cell current index are presented from 12 cells per group derived from 6 mice per genotype. ( $* 00.05$, unpaired $t$-test.)
} 


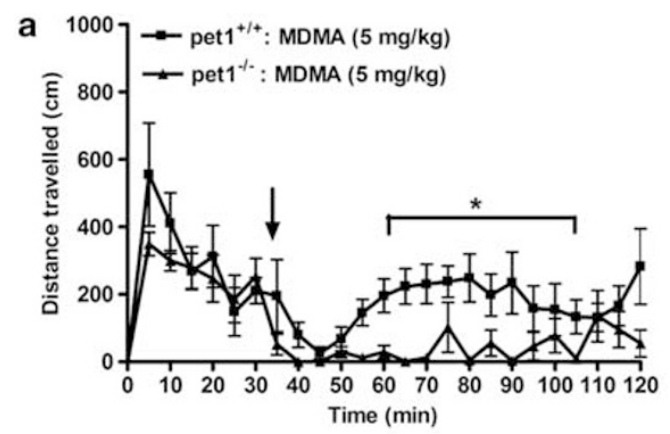

C
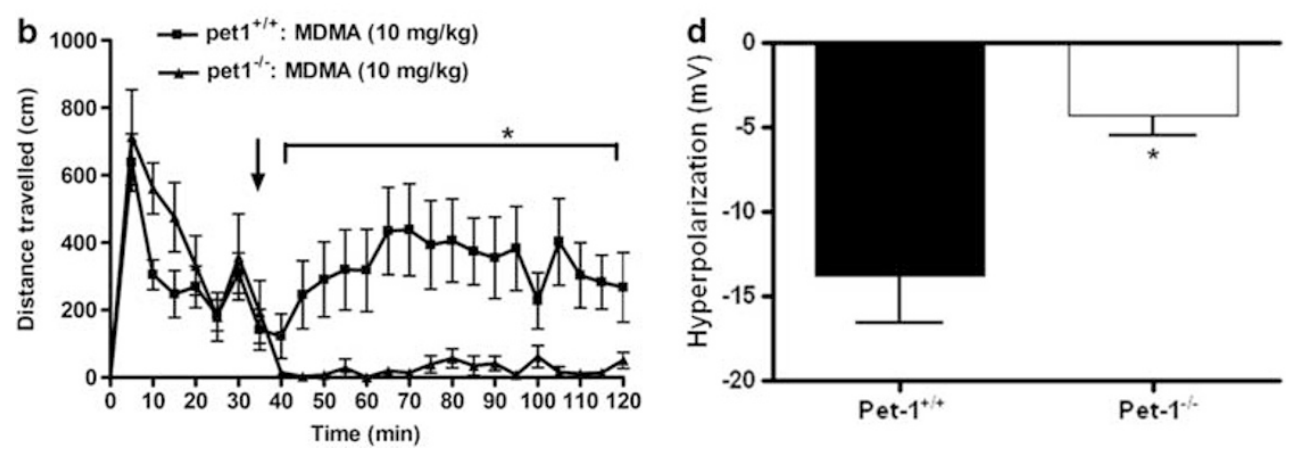

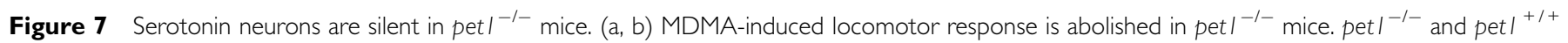
littermate controls were injected with $5 \mathrm{mg} / \mathrm{kg}$ (a) or $10 \mathrm{mg} / \mathrm{kg}$ (b) MDMA after a 30-min acclimatization and then locomotor activity was measured for the next 90 min. * $p<0.05$, two-way ANOVA followed by Bonferroni correction for multiple comparisons. (c, d) 5-CT-induced changes in membrane potential recorded from the ventromedial subfield of the dorsal raphe. (c) Representative chart recording (in current clamp mode) of a neuron from pet ${ }^{+/+}$mice showing the hyperpolarization induced by $5-\mathrm{CT}(100 \mathrm{nM})$ bath application. (d) The graph summarizes the findings from all of the recorded cells identified as $5-\mathrm{HT}$ containing in the pet $)^{+/+}$mice or as $5-\mathrm{HT}$ precursor neurons by $\beta$-galactosidase staining in the slices from pet $I^{-/-}$mice $(\mathrm{N}=24$ per genotype, $* p<0.00$ I, unpaired $t$-test).

\section{Implications of These Findings for Psychiatric Drug Discovery}

Although there is little debate regarding clozapine's unique efficacy in treating schizophrenia, the molecular and neuronal determinant(s) of clozapine's actions remain highly controversial. Some groups have proposed that clozapine is uniquely efficacious because of a combination of relatively low D2 receptor affinity (and associated fast dissociation rate) and/or high D4 dopamine receptor affinity (Kapur and Seeman, 2001; Seeman et al, 1997). This approach has led to the successful development of drugs like amisulpride that are relatively selective D2/D3 dopamine receptor antagonists (Schoemaker et al, 1997).

Others have suggested that clozapine via its principal metabolite $\mathrm{N}$-desmethylclozapine potentiates NMDA-receptor function by virtue of M1 muscarinic receptor agonism (Sur et al, 2003; Wittmann et al, 2005). This hypothesis has led to a new crop of muscarinic subtype-selective allosteric potentiators currently being developed (Conn and Roth, 2008; Gray and Roth, 2007). Furthermore, it has also been shown that clozapine can potentiate NMDA activity by directly binding to glycine B site (Bressan et al, 2005; Javitt et al, 2005; Schwieler et al, 2008), thus contributing to its unique clinical efficacy. Clearly, however, the PCP-induced PPI disruption and hyperlocomoter response in mice do not model all aspects of schizophrenia and, therefore, other potential actions of clozapine were not addressed here.
Others, most prominently Meltzer and colleagues (Nash et al, 1988), who discovered that clozapine and related atypical antipsychotic drugs were characterized by relatively higher affinities for postsynaptic $5-\mathrm{HT}_{2 \mathrm{~A}}$ serotonin receptors (HTR2A) when compared with D2 receptors, suggested that a balanced antagonism of $5-\mathrm{HT}_{2 \mathrm{~A}} / \mathrm{D} 2$ was required. This hypothesis led to the successful development of many currently prescribed atypical antipsychotic drugs, although none of them recapitulates the unique efficacy of clozapine (Lieberman et al, 2005). Meltzer and colleagues (Li et al, 2009) have also reported a requirement for cortical postsynaptic $5-\mathrm{HT}_{1 \mathrm{~A}}$ receptors in mediating certain actions of clozapine and related atypical antipsychotic drugs. Based on the relatively high affinity of clozapine for various 5-HT receptors, a number of attempts have been made to develop clozapine-like atypical antipsychotic drugs that function as inverse agonists for various postsynaptic $5-\mathrm{HT}_{2 \mathrm{~A}}, 5-\mathrm{HT}_{2 \mathrm{C}}$, $5-\mathrm{HT}_{6}$, and 5- $\mathrm{HT}_{7}$ receptors (Gray and Roth, 2007), although, to date, these efforts have not yielded approved atypical antipsychotic drugs.

Many other molecular target-based approaches for developing atypical antipsychotic drugs are currently underway. These include targeting various components of the glutamate synapse (eg, mGluR2/3 allosteric potentiators, mGluR5 potentiators, GlyT1 glycine transporter inhibitors, and AMPA receptor potentiators), nicotinic acetylcholine subtype-selective agents, phosphodiesterase $10 \mathrm{~A}$ inhibitors, NK3-neurokinin receptor antagonists, and others (Conn 
and Roth, 2008; Gray and Roth, 2007; Karam et al, 2010). At present, it is unknown which, if any, of the above mechanistically designed (or single-target-based) approaches to treat schizophrenia require an intact presynaptic serotonergic neuronal system, although we are actively engaged in evaluating many of these drugs in $p e t 1^{-1-}$ mice (PN Yadav et al, unpublished).

By way of contrast, our results indicate that the presynaptic component of the serotonin neuronal system is a key determinant of clozapine's antipsychotic-like actions in mice in vivo. Therefore, a key feature for new antipsychotics would be a requirement for activity at the presynaptic component of the serotonergic neuronal system while simultaneously targeting various postsynaptic receptors to yield maximum efficacy. Clearly, designing such drugs with a focused serotonergic action, while minimizing side effects, will be the challenge for the next revolution in treating schizophrenia.

\section{DISCLOSURE}

Dr Roth in the past 24 months has been a consultant for Bristol Myers Squibb, Otsuka Pharmaceuticals, Merck, Medivation, Galenea Pharmaceuticals, the National Institutes of Health, Invitrogen, and Albany Molecular Researech, and has received royalty payments from licensing of 5-HT receptor patents (which are owned by UNC and Case Western Reserve University) to Galena Pharmaceuticals. Drs Shoichet and Irwin are co-founders of SeaChange, and Dr Keiser is an employee of SeaChange. The other authors declare no conflict of interest.

\section{ACKNOWLEDGEMENTS}

This study was supported by U19MH82441, RO1MH61887, RO1MH075047, the NIMH Psychoactive Drug Screening Program Contract, and the Michael Hooker Distinguished Professorship to BLR. Additional support was from GM71896 (to JJI and BKS) MH075047 to SGB, MH082611 to LKC and the Rogers Family Foundation (to MJK, JJI, and BKS). BKS thanks Tudor Oprea for a gift of the WOMBAT database and John Overington for early access to ChEMBL.

\section{REFERENCES}

Abbas AI, Yadav PN, Yao WD, Arbuckle MI, Grant SG, Caron MG et al (2009). PSD-95 is essential for hallucinogen and atypical antipsychotic drug actions at serotonin receptors. J Neurosci 29: 7124-7136.

Angst J, Jaenicke U, Padrutt A, Scharfetter C (1971). Ergebnisse eines Doppelblindversuches von HF 1854* (8-Chlor-11(4-methyl-1-piperazinyl)-5H-dibenzo (b, e) $(1,4)$ diazepin) im Vergleich zu Levomepromazin. Pharmacopsychiatry 4: 192-200.

Armbruster BN, Roth BL (2005). Mining the receptorome. J Biol Chem 280: 5129-5132.

Bakshi VP, Swerdlow NR, Geyer MA (1994). Clozapine antagonizes phencyclidine-induced deficits in sensorimotor gating of the startle response. J Pharmacol Exp Ther 271: 787-794.

Beaulieu JM, Gainetdinov RR, Caron MG (2009). Akt/GSK3 signaling in the action of psychotropic drugs. Annu Rev Pharmacol Toxicol 49: 327-347.
Beaulieu JM, Marion S, Rodriguiz RM, Medvedev IO, Sotnikova TD, Ghisi V et al (2008). A beta-arrestin 2 signaling complex mediates lithium action on behavior. Cell 132: 125-136.

Beaulieu JM, Sotnikova TD, Marion S, Lefkowitz RJ, Gainetdinov RR, Caron MG (2005). An Akt/beta-arrestin 2/ PP2A signaling complex mediates dopaminergic neurotransmission and behavior. Cell 122: 261-273.

Beck SG, Pan YZ, Akanwa AC, Kirby LG (2004). Median and dorsal raphe neurons are not electrophysiologically identical. J Neurophysiol 91: 994-1005.

Belforte JE, Zsiros V, Sklar ER, Jiang Z, Yu G, Li Y et al (2010). Postnatal NMDA receptor ablation in corticolimbic interneurons confers schizophrenia-like phenotypes. Nat Neurosci 13: 76 .

Bolden C, Cusack B, Richelson E (1992). Antagonism by anitmuscarinic and neuroleptic compounds at the five cloned human muscarinic cholinergic receptors expressed in Chinese hamster ovary cells. J Pharm Exp Ther 260: 576-580.

Bressan RA, Erlandsson K, Stone JM, Mulligan RS, Krystal JH, Ell PJ et al (2005). Impact of schizophrenia and chronic antipsychotic treatment on [123I]CNS-1261 binding to N-methyl-Daspartate receptors in vivo. Biol Psychiatry 58: 41-46.

Carlsson A, Waters N, Carlsson ML (1999). Neurotransmitter interactions in schizophrenia-therapeutic implications. Eur Arch Psychiatry Clin Neurosci 249(Suppl 4): 37-43.

Conn PJ, Roth BL (2008). Opportunities and challenges of psychiatric drug discovery: roles for scientists in academic, industry, and government settings. Neuropsychopharmacology 33: $2048-2060$.

Creese I, Burt DR, Snyder SH (1976). Dopamine receptor binding predicts clinical and pharmacological potencies of antischizophrenic drugs. Science 192: 481-483.

Enna SJ, Bennett Jr JP, Burt DR, Creese I, Snyder SH (1976). Stereospecificity of interaction of neuroleptic drugs with neurotransmitters and correlation with clinical potency. Nature 263: $338-341$.

Fink H, Morgenstern R, Oelssner W (1984). Clozapine-a serotonin antagonist? Phamacol Biochem Behav 20: 513-517.

Geyer MA, Braff DL (1987). Startle habituation and sensorimotor gating in schizophrenia and related animal models. Schizophr Bull 13: 643-668.

Gray JA, Roth BL (2007). The pipeline and future of drug development in schizophrenia. Mol Psychiatry 12: 904 .

Hendricks T, Francis N, Fyodorov D, Deneris ES (1999). The ETS domain factor Pet-1 is an early and precise marker of central serotonin neurons and interacts with a conserved element in serotonergic genes. J Neurosci 19: 10348-10356.

Hendricks TJ, Fyodorov DV, Wegman LJ, Lelutiu NB, Pehek EA, Yamamoto B et al (2003). Pet-1 ETS gene plays a critical role in 5-HT neuron development and is required for normal anxietylike and aggressive behavior. Neuron 37: 233-247.

Hert J, Keiser MJ, Irwin JJ, Oprea TI, Shoichet BK (2008). Quantifying the relationships among drug classes. J Chem Inf Model 48: 755-765.

Hippius H (1999). A historical perspective of clozapine. J Clin Psychiatry 60(Suppl 12): 22-23.

Hopkins AL, Groom CR (2002). The druggable genome. Nat Rev Drug Discov 1: 727-730.

James CA, Weininger D, Delaney J (1992). Daylight Theory Manual. Daylight Chemical Information Systems, Inc.: Mission Viejo, CA.

Javitt DC, Duncan L, Balla A, Sershen H (2005). Inhibition of system A-mediated glycine transport in cortical synaptosomes by therapeutic concentrations of clozapine: implications for mechanisms of action. Mol Psychiatry 10: 275-287.

Javitt DC, Zukin SR (1991). Recent advances in the phencyclidine model of schizophrenia. Am J Psychiatry 148: 1301-1308. 
Jensen P, Farago AF, Awatramani RB, Scott MM, Deneris ES, Dymecki SM (2008). Redefining the serotonergic system by genetic lineage. Nat Neurosci 11: 417-419.

Kane J, Honigfield G, Singer J, Meltzer HY (1988). Clozapine for the treatment-resistant schizophrenic. Arch Gen Psychiatry 45: 789-796.

Kapur S, Seeman P (2001). Does fast dissociation from the dopamine $\mathrm{d}(2)$ receptor explain the action of atypical antipsychotics?: A new hypothesis. Am J Psychiatry 158: 360-369.

Karam CS, Ballon JS, Bivens NM, Freyberg Z, Girgis RR, LizardiOrtiz JE et al (2010). Signaling pathways in schizophrenia: emerging targets and therapeutic strategies. Trends Pharmacol Sci 31: 381-390.

Keiser MJ, Roth BL, Armbruster BN, Ernsberger P, Irwin JJ, Shoichet BK (2007). Relating protein pharmacology by ligand chemistry. Nat Biotechnol 25: 197-206.

Keiser MJ, Setola V, Irwin JJ, Laggner C, Abbas AI, Hufeisen SJ et al (2009). Predicting new molecular targets for known drugs. Nature 462: 175-181.

Li Z, Prus AJ, Dai J, Meltzer HY (2009). Differential effects of M1 and 5-hydroxytryptamine1A receptors on atypical antipsychotic drug-induced dopamine efflux in the medial prefrontal cortex. J Pharmacol Exp Ther 330: 948-955.

Lieberman JA, Stroup TS, McEvoy JP, Swartz MS, Rosenheck RA, Perkins DO et al (2005). Effectiveness of antipsychotic drugs in patients with chronic schizophrenia. N Engl J Med 353: 1209-1223.

Linnet K (2002). Glucuronidation of olanzapine by cDNAexpressed human UDP-glucuronosyltransferases and human liver microsomes. Hum Psychopharmacol 17: 233-238.

Magalhaes AC, Holmes KD, Dale LB, Comps-Agrar L, Lee D, Yadav PN et al (2010). CRF receptor 1 regulates anxiety behavior via sensitization of 5-HT2 receptor signaling. Nat Neurosci 13: 622-629.

Manning G, Whyte DB, Martinez R, Hunter T, Sudarsanam S (2002). The protein kinase complement of the human genome. Science 298: 1912-1934.

Mansbach RS, Geyer MA (1989). Effects of phencyclidine and phencyclidine biologs on sensorimotor gating in the rat. Neuropsychopharmacology 2: 299-308.

Matsuoka S, Huang M, Elledge SJ (1998). Linkage of ATM to cell cycle regulation by the Chk2 protein kinase. Science 282: 1893-1897.

Meltzer HY, Alphs L, Green AI, Altamura AC, Anand R, Bertoldi A et al (2003). Clozapine treatment for suicidality in schizophrenia: International Suicide Prevention Trial (InterSePT). Arch Gen Psychiatry 60: 82-91.

Meltzer HY, Matsubara S, Lee J-C (1989). Classification of typical and atypical antipsychotic drugs on the basis of dopamine D-1, D-2 and serotonin2 pKi values. J Pharmacol Exp Ther 251: 238-246.

Meltzer HY, Okayli G (1995). Reduction of suicidality during clozapine treatment of neuroleptic-resistant schizophrenia: impact on risk-benefit assessment. Am J Psychiatry 152: 183-190.

Miller RJ, Hiley CR (1974). Anti-muscarinic properties of neuroleptics and drug-induced parkinsonism. Nature (London) 248: $546-547$.

Mohn AR, Gainetdinov RR, Caron MG, Koller BH (1999). Mice with reduced NMDA receptor expression display behaviors related to schizophrenia. Cell 98: 427-436.

Nash JF, Meltzer HY, Gudelsky GA (1988). Antagonism of serotonin receptor mediated neuroendocrine and temperature responses by atypical neuroleptics in the rat. Eur J Pharmacol 151: 463-469.

Newman-Tancredi A, Gavaudan S, Conte C, Chaput C, Touzard M, Verriele L et al (1998). Agonist and antagonist actions of antipsychotic agents at 5-HT1A receptors: a [35S]GTPgammaS binding study. Eur J Pharmacol 355: 245-256.

Olah M, Bologa C, Oprea TI (2004). An automated PLS search for biologically relevant QSAR descriptors. J Comput Aided Mol Des 18: 437-449.

Oprea TI, Tropsha A, Faulon JL, Rintoul MD (2007). Systems chemical biology. Nat Chem Biol 3: 447-450.

Peroutka SJ, Lebovitz RM, Snyder SH (1981). Two distinct serotonin receptors with distinct physiological functions. Science 212: 827-829.

Purcell SM, Wray NR, Stone JL, Visscher PM, O'Donovan MC, Sullivan PF et al (2009). Common polygenic variation contributes to risk of schizophrenia and bipolar disorder. Nature 460: 748-752.

Rollema H, Lu Y, Schmidt AW, Zorn SH (1997). Clozapine increases dopamine release in prefrontal cortex by 5-HT1A receptor activation. Eur J Pharmacol 338: R3-R5.

Roth BL, Ciaranello RD, Meltzer HY (1992). Binding of typical and atypical antipsychotic agents to transiently expressed 5-HT1C receptors. J Pharmacol Exp Ther 260: 1361-1365.

Roth BL, Craigo SC, Choudhary MS, Uluer A, Monsma Jr FJ, Shen $Y$ et al (1994). Binding of typical and atypical antipsychotic agents to 5- hydroxytryptamine-6 and 5-hydroxytryptamine-7 receptors. J Pharmacol Exp Ther 268: 1403-1410.

Roth BL, Sheffler DJ, Kroeze WK (2004). Magic shotguns versus magic bullets: selectively non-selective drugs for mood disorders and schizophrenia. Nat Rev Drug Discov 3: 353-359.

Schoemaker H, Claustre Y, Fage D, Rouquier L, Chergui K, Curet O et al (1997). Neurochemical characteristics of amisulpride, an atypical dopamine D2/D3 receptor antagonist with both presynaptic and limbic selectivity. J Pharmacol Exp Ther 280: 83-97.

Schwieler L, Linderholm KR, Nilsson-Todd LK, Erhardt S, Engberg G (2008). Clozapine interacts with the glycine site of the NMDA receptor: electrophysiological studies of dopamine neurons in the rat ventral tegmental area. Life Sci 83: 170-175.

Scott MM, Wylie CJ, Lerch JK, Murphy R, Lobur K, Herlitze S et al (2005). A genetic approach to access serotonin neurons for in vivo and in vitro studies. Proc Natl Acad Sci USA 102: 16472-16477.

Seeman P, Corbett R, Van Tol HH (1997). Atypical neuroleptics have low affinity for dopamine D2 receptors or are selective for D4 receptors. Neuropsychopharmacology 16: 93-110, discussion 111-135.

Senn HJ, Jungi WF, Kunz H, Poldinger W (1977). Clozapine and agranulocytosis. Lancet 1: 547.

Shi J, Levinson DF, Duan J, Sanders AR, Zheng Y, Pe'er I et al (2009). Common variants on chromosome 6p22.1 are associated with schizophrenia. Nature 460: 753-757.

Stefansson H, Ophoff RA, Steinberg S, Andreassen OA, Cichon S, Rujescu D et al (2009). Common variants conferring risk of schizophrenia. Nature 460: 744-747.

Stefansson H, Rujescu D, Cichon S, Pietilainen OP, Ingason A, Steinberg $S$ et al (2008). Large recurrent microdeletions associated with schizophrenia. Nature 455: 232-236.

Sur C, Mallorga PJ, Wittmann M, Jacobson MA, Pascarella D, Williams JB et al (2003). N-desmethylclozapine, an allosteric agonist at muscarinic 1 receptor, potentiates N-methyl-D-aspartate receptor activity. Proc Natl Acad Sci USA 100: 13674-13679.

Van Tol HH, Bunzow JR, Guan HC, Sunahara RK, Seeman P, Niznik HB et al (1991). Cloning of the gene for a human dopamine D4 receptor with high affinity for the antipsychotic clozapine. Nature 350: 610-614.

Wittmann M, Marino MJ, Henze DA, Seabrook GR, Conn PJ (2005). Clozapine potentiation of N-methyl-D-aspartate receptor currents in the nucleus accumbens: role of NR2B and protein kinase A/Src kinases. J Pharmacol Exp Ther 313: 594-603.

Supplementary Information accompanies the paper on the Neuropsychopharmacology website (http://www.nature.com/npp) 